\title{
PKC $\varepsilon$ Activation Prevents Synaptic Loss, A $\beta$ Elevation, and Cognitive Deficits in Alzheimer's Disease Transgenic Mice
}

\author{
Jarin Hongpaisan, ${ }^{1,2}$ Miao-Kun Sun, ${ }^{1}$ and Daniel L. Alkon ${ }^{1}$ \\ ${ }^{1}$ Blanchette Rockefeller Neurosciences Institute at West Virginia University, Morgantown, West Virginia 26505, and '2Laboratory of Neurobiology, National \\ Institute of Neurological Disorders and Stroke, National Institutes of Health, Bethesda, Maryland 20892
}

\begin{abstract}
Among the pathologic hallmarks of Alzheimer's disease (AD) neurodegeneration, only synaptic loss in the brains of AD patients closely correlates with the degree of dementia in vivo. Here, we describe a molecular basis for this AD loss of synapses: pathological reduction of synaptogenic PKC isozymes and their downstream synaptogenic substrates, such as brain-derived neurotrophic factor. This reduction, particularly of PKC $\alpha$ and $\varepsilon$, occurs in association with elevation of soluble $\beta$ amyloid protein $(\mathrm{A} \beta)$, but before the appearance of the amyloid plaques or neuronal loss in the Tg2576 AD transgenic mouse strain. Conversely, treatment of the Tg2576 mouse brain with the PKC activator, bryostatin-1, restores normal or supranormal levels of PKC $\alpha$ and $\varepsilon$, reduces the level of soluble A $\beta$, prevents and/or reverses the loss of hippocampal synapses, and prevents the memory impairment observed at 5 months postpartum. Similarly, the PKC $\varepsilon$-specific activator, DCP-LA, effectively prevents synaptic loss, amyloid plaques, and cognitive deficits (also prevented by bryostatin-1) in the much more rapidly progressing 5XFAD transgenic strain. These results suggest that synaptic loss and the resulting cognitive deficits depend on the balance between the lowering effects of $A \beta$ on $\mathrm{PKC} \alpha$ and $\varepsilon$ versus the lowering effects of PKC on $\mathrm{A} \beta$ in AD transgenic mice.
\end{abstract}

\section{Introduction}

Synaptic loss is the only pathological finding in the brains of Alzheimer's disease (AD) patients that is closely correlated with the degree of dementia in vivo (Terry et al., 1991). Such synaptic markers as immunohistochemically labeled synaptophysin (staining for presynaptic vesicles) are markedly reduced in the brains of AD patients (Masliah et al. 1991; Terry et al., 1991). The two pathologic hallmarks of $\mathrm{AD}$, amyloid plaques and neurofibrillary tangles, however, are only weakly correlated with the degree of dementia in $\mathrm{AD}$ patients.

The molecular pathogenesis of $\mathrm{AD}$ is not clearly understood. Current evidence suggests that soluble $\beta$ amyloid protein $(\mathrm{A} \beta$; more specifically, oligomers) is involved in the synaptic loss. Soluble $\mathrm{A} \beta$ has also been shown to reduce PKC isozymes (Favit et al., 1998 ) and to downregulate PKC by the binding of PKC to a putative PKC substrate domain (A $\beta 28-30$ ) (Lee et al., 2004).

An early reduction of PKC isozymes in $\mathrm{AD}$ brains could be closely linked to $\mathrm{A} \beta$-induced synaptic loss/deficits. Both PKC $\varepsilon$ and PKC $\alpha$ are important for synaptogenesis. The high abundance of PKC $\varepsilon$ in presynaptic nerve fibers suggests a role in neurite outgrowth, synapse formation, and neurotransmitter release (Shirai et al., 2008). Nontoxic drugs activating PKC $\alpha$ and $\varepsilon$ (Nelson and Alkon, 2009) can promote synaptogenesis under nonpathological conditions and prevent synaptic loss under

\footnotetext{
Received 0ct. 4, 2010; accepted 0ct. 31, 2010.

We are indebted to Dr. Thomas I Nelson, Blanchette Rockefeller Neurosciences Institute, for providing DCP-LA and helpful advice. We also thank Tina Shinkovich and Dee DeNuto for assisting in the preparation of this manuscript and Wen Zheng for technical assistance.

Correspondence should be addressed to Jarin Hongpaisan, Blanchette Rockefeller Neurosciences Institute, West Virginia University, 8 Medical Center Drive, Morgantown, WV 26505. E-mail: jhongpaisan@brni.org.

DOI:10.1523/JNEUROSCI.5209-10.2011

Copyright $\odot 2011$ the authors $\quad 0270-6474 / 11 / 310630-14 \$ 15.00 / 0$
}

pathological conditions (Hongpaisan and Alkon, 2007; Sun et al., 2008, 2009). PKC $\varepsilon$ activity and expression levels are lower in the cerebral cortex of AD patients (Saitoh et al., 1989; Matsushima et al., 1996). PKC $\alpha$ is also reduced in fibroblasts of AD patients (Favit et al., 1998).

In the present study, therefore, we studied the effects of bryostatin-1 (an activator of both $\alpha$ and $\varepsilon$ isozymes of PKC) and DCP-LA (a PKC $\varepsilon$-specific activator) on A $\beta$, synaptic structures and numbers, amyloid plaques, and hippocampal-dependent memory functions. We studied these effects during the slow progression of $\mathrm{AD}$ pathogenesis in the $\mathrm{AD}$ transgenic mice designated $\mathrm{Tg} 2576$, which contain the single Swedish mutation, as well as during the more aggressive $\mathrm{AD}$ pathogenesis of the $5 \mathrm{XFAD}$ mouse strain, which contains five familial Alzheimer's disease (FAD) mutations (Swedish, Florida, and London human APP(695) mutations and M146L and L286V PS1 mutations). In the Tg2576 mice we were able to analyze levels of soluble $A \beta$, numbers of synapses with particular morphologies, PKC isozymes, brain-derived neurotrophic factor (BDNF), and astrocytic activity at 5 months postpartum (when no amyloid plaques were detectable) with and without treatment with bryostatin-1, which reversed the observed deficits.

In the 5XFAD mouse strain, both bryostatin-1 and DCP-LA completely reversed the marked deficits of spatial maze learning and memory at 5 months postpartum when amyloid plaques were already abundantly distributed throughout the hippocampus. Similarly, DCP-LA treatment largely prevented both the deposition of the amyloid plaques and the loss of synaptic connections in the 5XFAD mice.

\section{Materials and Methods}

Water maze training. Male mice, $\sim 2$ months old, were purchased and housed for 1 week before the experiment. Two types of AD transgenic mice were used: (1) Tg2576 (genotype: hemizygous for 129S6.Cg- 
$\operatorname{Tg}$ (APPSWE)2576Kha N20+?; Taconic), with wild-type mice used as control, and (2) B6SJL-Tg(APPSwFILon,PSEN1*M146L ${ }^{\star}$ L286V)6799Vas/J (genotype: hemizygous for APPSwFILon,PSEN1 ${ }^{\star}$ M146L ${ }^{\star}$ L286V)6799Vas, JAXEAST:AX11; 5XFAD; The Jackson Laboratory), with B6SJLF1/J JAXEAST:AX27 as the control groups.

Bryostatin-1 (from the National Cancer Institute, National Institutes of Health, Bethesda, MD for Tg2576: 20 mg/kg, i.p.; from Sigma-Aldrich for 5XFAD: $20 \mathrm{mg} / \mathrm{m}^{2}$, tail i.v.) and DCP-LA (from Dr. Thomas Nelson, Blanchette Rockefeller Neurosciences Institute, Morgantown, WV, 3 $\mathrm{mg} / \mathrm{kg}$, i.p.) were administered 2 doses/week for 12 weeks. Nontreated groups received the same vehicle volumes, mechanism of delivery, and frequency of administration as the treated groups (see Fig. $1 A$ ). The first training in the spatial water maze task began on the 10th day after the last dose. Mice were moved to the test room in their home cages at least $1 \mathrm{~h}$ before daily trials. The maze pool had a diameter of $114 \mathrm{~cm}$ and height of $60 \mathrm{~cm}$ and was filled with $40 \mathrm{~cm} \mathrm{H}_{2} \mathrm{O}\left(22 \pm 1^{\circ} \mathrm{C}\right)$, mixed with $200 \mathrm{ml}$ of nontoxic white tempera (BesTemp, Certified Color Corporation). The maze was divided into four quadrants. Mice were trained for 5-6 d (3-4 trials/d) to find a hidden platform ( $9 \mathrm{~cm}$ diameter $)$, centered in one of the quadrants and submerged $\sim 2 \mathrm{~cm}$ below the water surface. At the start of all trials, mice were placed individually in the water facing the maze wall, using different starting positions for each trial, and allowed to swim until they found the platform, where they remained for $20 \mathrm{~s}$ before being returned to their home cages. A mouse that failed to find the platform within $1.5 \mathrm{~min}$ was guided there by the investigator, with $90 \mathrm{~s}$ scored. The swim path was recorded with a video-tracking system that computed latency to the platform, swim distance, and percentage of time spent in the quadrants. After the training trials, a probe trial (a quadrant test or retention trial) was given with the platform removed to assess memory retention for its location by the distance the mouse moved in the quadrants. The video-tracking system tracked the animal's movements in each quadrant during a period of $1 \mathrm{~min}$. A visible platform test (with the platform marked with a pole that protruded 9 inches above the water surface but at a new location) was given after the probe test to evaluate sensorimotor ability and motivation for an escape of the animals.

Tissue preparation for confocal microscopy. Under anesthesia (pentobarbital, $80 \mathrm{mg} / \mathrm{kg}$ body weight, i.p.), animals were perfused through the left cardiac ventricle with PBS (room temperature) by gravity to wash out the blood and then lightly fixed with $4 \%$ paraformaldehyde in PBS at room temperature instead of using a cold fixative, because hypothermia reduces the number of dendritic spines (Kirov et al., 2004). Brains were removed, postfixed at $4^{\circ} \mathrm{C}$ overnight, and stored in PBS at $4^{\circ} \mathrm{C}$. Right dorsal hippocampi were dissected and sectioned with a vibratome at 300 $\mu \mathrm{m}$ thickness. The hippocampal sections were further fixed with $4 \%$ paraformaldehyde in PBS at room temperature for $2 \mathrm{~h}$ and then resectioned to $35 \mu \mathrm{m}$ thickness in preparation for immunohistochemistry testing, amyloid plaque staining, cell viability testing, and apoptotic cell staining.

Immunohistochemistry. Immunohistochemistry experiments were modified from our previous study (Hongpaisan and Alkon, 2007). After washing the hippocampal sections 3 times (each time for a period of 5 $\mathrm{min}$ ) with PBS, the sections were incubated for $1 \mathrm{~h}$ at room temperature in a blocking solution consisting of $15 \%$ horse serum and $0.1 \%$ Triton X-100 in PBS. Tissue sections were incubated free floating at room temperature overnight in the blocking solution consisting of primary antibodies against the dendritic spine marker, spinophilin (rabbit polyclonal IgG; 1:100; Millipore), the presynaptic vesicle membrane protein synaptophysin (mouse monoclonal IgG; 1:2000; Millipore), A $\beta$ (mouse monoclonal 6E10 antibody; 1:100; Millipore), amyloid oligomer (rabbit polyclonal A11 antibody; 1:100; Millipore), amyloid precursor protein antibody (APP; rabbit polyclonal IgG, 1:75, Abcam), and antibodies to $\alpha$-synuclein (mouse monoclonal IgG, Santa Cruz Biotechnology, 1:100), PKC $\varepsilon$ (rabbit polyclonal IgG; 1:100; Millipore), PKC $\alpha$ (mouse monoclonal IgG; 1:100; Millipore), and BDNF (mouse monoclonal IgG; 1:50; Santa Cruz Biotechnology). Sections were then washed 3 times (each time for a period of $5 \mathrm{~min}$ ) with PBS and incubated with biotinylated horse anti-mouse antibody (1:20; Vector Laboratories) for $3 \mathrm{~h}$ at room temperature. Tissue sections were washed 3 times (each time for a period of $5 \mathrm{~min}$ ) and then incubated with Alexa Fluor 568 goat anti-rabbit IgG
(1:200; Invitrogen) and streptavidin conjugated with Alexa Fluor 488 ( $1: 100$; Invitrogen) for $3 \mathrm{~h}$ at room temperature. All sections were washed 3 times (each time for a period of $5 \mathrm{~min}$ ), mounted on glass slides with Vectashield mounting medium with 4',6-diamidino-2-phenylindole (DAPI; Vector Laboratories) to counterstain nuclei and sealed with cover glasses.

Amyloid plaque staining. Amyloid plaques were stained with Thioflavin-S staining, as modified from a previous study (Bussière et al., 2004). Hippocampal slices, at $35 \mu \mathrm{m}$ thickness, were further fixed with PBS at room temperature for $1 \mathrm{~h}$, washed with PBS, and incubated 10 $\min$ in $0.25 \%$ potassium permanganate. The sections were washed in PBS, immersed in $2 \%$ oxalic acid until they appeared white, then washed in distilled water and stained for $10 \mathrm{~min}$ with a solution of $0.015 \%$ Thioflavin-S and 50\% ethanol in PBS. The sections were washed with $50 \%$ ethanol and then placed in distilled water. The sections were then mounted on glass slides, air dried, covered with a glass cover using Vectashield mounting medium without DAPI (Vector Laboratories), and sealed with nail polish. All other chemicals were from Sigma-Aldrich.

Apoptotic cell staining. Apoptotic cells were detected with terminal deoxynucleotidyltransferase (TdT)- mediated dUTP nick end labeling (TUNEL; R\&D Systems) with a free-floating technique. The staining was modified from the standard procedure as described in the TUNEL kits. Sections were washed with deionized (DNase free) water (at room temperature, 3 times (each for a period of $5 \mathrm{~min}$ ) and treated with proteinase $\mathrm{K}(1: 200)$ in deionized water for $2 \mathrm{~h}$ at $37^{\circ} \mathrm{C}$. After washing with deionized water at room temperature 3 times (each for a period of $5 \mathrm{~min}$ ), sections were placed in TdT labeling buffer for $5 \mathrm{~min}$ at room temperature. Sections were incubated with the labeling reaction mix (TdT dNTP mix, $\mathrm{Mn}^{2+}$, and TdT enzyme; all 1:50 in TdT labeling buffer) in a humidity chamber and slightly shaken with a rocking platform shaker at room temperature overnight. Sections were stored in TdT stop buffer for 10 min at room temperature and then washed 3 times with PBS (room temperature) for $5 \mathrm{~min}$ each. Sections were then incubated with StrepFluor solution (1:50) in PBS at room temperature for $3 \mathrm{~h}$ and washed 2 times with $0.1 \%$ Tween 20 (Sigma-Aldrich) in PBS at room temperature for $5 \mathrm{~min}$ each. After washing with deionized water at room temperature for $5 \mathrm{~min}$, sections were mounted with Vectashield mounting medium containing DAPI to counterstain nuclei.

DiI staining. Dendritic spines were visualized with $1,1^{\prime}$-dioctadecyl3,3,3' $3^{\prime}$-tetramathyl-indocarbocyanineperchlorate (DiI; Invitrogen), as described in our previous study (Hongpaisan and Alkon, 2007). The tips of glass electrodes, prepared to be used for electrophysiological experiments, were immersed for $10 \mathrm{~s}$ (2-3 times) in 5\% (w/v) DiI in dichloromethane (Sigma-Aldrich) and air dried at room temperature for $1 \mathrm{~h}$. The tips of DiI-coated electrodes were inserted, broken, and left in the strata oriens of the CA1 area of hippocampal sections at $300 \mu \mathrm{m}$ thickness (3-4 electrode tips/slice). After maintenance in PBS at $4^{\circ} \mathrm{C}$ overnight to allow DiI to diffuse in the plasma membrane of CA1 neurons, hippocampal sections were then resectioned to $35 \mu \mathrm{m}$ thickness and mounted on glass slides, using distilled water as a mounting medium.

Confocal microscopy. Experiments consisted of the use of three to four mice per group (control, transgenic, and transgenic with drug). Three sections of the hippocampal area $35 \mu \mathrm{m}$ in thickness were dissected from each mouse. From these sections, three to four confocal images of the CA1 hippocampal area at $0.5-1 \mu \mathrm{m}$ in thickness were used totaling $\sim 30-40$ images per mouse. Hippocampal slices were imaged with a Zeiss Axiovert 200M microscope equipped with 510 confocal scanning system or a Zeiss Axio Observer Z1 microscope equipped with 710 confocal scanning system, using $63 \times$ Plan-Apochromat oil-immersion objective (1.4 numerical aperture). Confocal images were collected with line scan mode and pinhole about 1.00 Airy unit and $0.5-1 \mu \mathrm{m}$ in thickness.

Quantification of confocal images. The levels of soluble $\mathrm{A} \beta-42, \mathrm{PKC} \varepsilon$, $\operatorname{PKC} \alpha$, and BDNF were evaluated from immunofluorescence intensity. Confocal images, obtained with a Zeiss confocal microscope, were stored and quantified offline with the ImageJ program (http://rsb.info.nih.gov/ $\mathrm{ij} /$ ). The control data were set at $100 \%$, and all other experimental data were defined as percentage of their controls: (1) intracellular soluble $\mathrm{A} \beta-42, \mathrm{PKC} \alpha$, and BDNF levels in CA1 pyramidal neurons were determined at the single-cell level by obtaining fluorescence intensity in each 
perinuclear region of CA1 cell bodies (5-10 neurons per one CA1 stratum pyramidale area image, two areas per hippocampal section, three hippocampal sections per animal, and three to four animal per experiment condition); (2) PKC $\varepsilon$ levels in mossy fibers (consisting of axons from dentate gyrus neurons whose axonal boutons form synapses on the pyramidal neurons in the hippocampal CA3 area) were measured by obtaining fluorescence intensity in three randomly selected areas of mossy fiber per hippocampal slices, three hippocampal slices per animals, and three to four animals per experimental condition.

$\mathrm{PKC} \varepsilon$ levels in presynaptic axonal boutons in stratum radiatum of the hippocampal CA1 area were identified by double immunohistochemistry of PKC $\varepsilon$ and the axonal bouton marker synaptophysin. The number of axonal boutons with and without PKC $\varepsilon$ (from CA3 neurons that terminated on dendritic spines in the CA1 area) was quantified on line by the Zen program on the confocal microscope under colocalization mode.

The appearance of spinophilin and amyloid plaques in a $63 \times 63 \mu \mathrm{m}$ image taken from the stratum radiatum of the hippocampal CA1 area (where proximal dendrites of CA1 pyramidal neurons are located) were analyzed with the photographic negative after background subtraction. By collecting confocal images at $0.8 \mu \mathrm{m}$ in thickness from $30-40$ confocal sections per experimental condition of the hippocampal CA1 area, the overlapping of dendritic spines or axonal boutons was minimized. The total numbers of dendritic spines (spinophilin granules) of proximal dendrites and amyloid plaques were then obtained by grain counting.

Dendritic spines stained with DiI ( $568 \mathrm{~nm} />510 \mathrm{~nm}$; excitation/emission) in the strata radiatum were imaged with the 710 confocal scanning system, using $100 \times$ Plan-Apochromat oil-immersion objective (1.4 numerical aperture). Confocal images $(1024 \times 1024$ pixels $)$ were collected with line scan mode and a pinhole of about 1.00 Airy unit. A series of randomized confocal images were (taken every $0.45 \mu \mathrm{m}$ ) collected to count the dendritic spines of individual dendritic shafts. During analysis, a series of images was retrieved with the ImageJ program. Individual spines identified on one image were also verified on adjacent images to approximate the three-dimensional structure of the spines. Spines that had head diameters more than three times larger than the diameter of their necks and appeared in more than three planes of the images were identified as mushroom spines. Approximately 4-6 stacked image sets were obtained from each animal. All image sets were pooled and coded and the images were identified with unknown animal numbers and unknown treatments (double blind protocol).

Cell viability test. Hippocampal sections of $35 \mu \mathrm{m}$ thickness were placed on glass slides and mounted with cover glasses by using Vectashield mounting medium containing DAPI to stain nuclei. The number of nuclei of pyramidal neurons in the stratum pyramidale of the hippocampal CA1 area was counted within randomly selected frames under confocal microscopic visualization (three random areas per hippocampal sections, three hippocampal sections per animals, and three to four animals per experiment condition). All pyknotic nuclei of nonviable cells were visualized and counted.

Astrocytic activity. Astrocytic activity was studied by immunohistochemistry (as described above) using the astrocyte marker glial fibrillary acidic protein (GFAP; rabbit monoclonal IgG; $1: 100$ ) as a primary antibody. The number of astrocytes was determined by counting astrocytes within an image area $(63 \times 63 \mu \mathrm{m})$ obtained with a confocal microscope and analyzed with the ImageJ program (as described above). The confocal images were randomly selected from stratum radiatum of the hippocampal CA1 area (two to three images per hippocampal sections, three hippocampal sections per animals, and three to four animals per experiment condition).

Electron microscopy. Electron microscopy was performed as described in our recent study (Hongpaisan and Alkon, 2007). The fixative was $2 \%$ glutaraldehyde and 3\% paraformaldehyde in PBS. Hippocampal slices at $100 \mu \mathrm{m}$ were washed three times with cold PBS and postfixed in cold $1 \%$ $\mathrm{OsO}_{4}$ for $1 \mathrm{~h}$ and then rinsed with cold distilled water. Slices were dehydrated in a cold, graded ethanol series. The next steps were all at room temperature. Sections were followed by resin embedding and sectioning using standard procedures. Ultrathin sections $(90 \mathrm{~nm})$ were stained with uranyl acetate and lead acetate and viewed at $100 \mathrm{kV}$ in a JEOL 200CX electron microscope. During double blind quantification, electron mi- crographs $\left(100 \mu \mathrm{m}^{2} \mathrm{CA} 1\right.$ area at $\left.5000 \times\right)$ were digitally zoomed up to $20,000 \times$ magnification by the Preview program in an Mac Pro computer with an Mac OS X operating system and a 30" monitor.

Spines were defined as structures that form synapses with axon boutons and do not contain mitochondria. Quantitative classification of dendritic spines as "mushroom" spines requires either of the following: (1) spine "heads" attached to a clearly distinguishable "neck" must have a cross-sectionally visualized diameter $>600 \mathrm{~nm}$ measured by the Image program; or (2) spine heads not attached to a clearly distinguishable neck must have both long and short axis lengths $>600 \mathrm{~nm}$ that could be cross-sectionally visualized. Experiments consisted of the use of three to four mice per group (control, transgenic, and transgenic with drug). Two sections of the hippocampus approximately $600 \mu \mathrm{m}$ were collected from each mouse. From each section, approximately five electron micrographs of the CA1 hippocampal area were taken. To eliminate the duplicate counting of synapses as described previously, we analyzed only one electron micrograph $(90 \mathrm{~nm})$ of tissue from each hippocampal CA1 area (Geinisman et al., 2001).

Per unit volume analysis. The number of dendritic spines (spinophilin grains), presynaptic axonal boutons (synaptophysin grains), amyloid plaques, or astrocytes was obtained from $63 \times 63 \mu \mathrm{m}$ confocal images with $0.8 \mu \mathrm{m}$ scanning thickness. Therefore, these data were collected from randomly selected volumes of the hippocampal CA1 area that were $\sim 63 \times 63 \times 0.8 \mu \mathrm{m}^{3}$. Synaptic density was determined from $100 \times 100$ $\mu \mathrm{m}$ electron micrographs taken from sections of hippocampi at the thickness of $90 \mathrm{~nm}$ (or $0.09 \mu \mathrm{m})$. Thus, synaptic density was determined from the volume of hippocampal CA1 area of $900 \mu^{3}{ }^{3}(100 \times 100 \times 0.09$ $\mu \mathrm{m})$. All of these data (except for amyloid plaques), as shown in the figures, were compared to the control wild-type mice that were set at $100 \%$.

Statistical analysis. All graphic data were shown as means \pm SEM. All data from EM and confocal images were first statistically analyzed by ANOVA single factor. Confocal and EM data with a significant overall difference among the groups as demonstrated with an ANOVA analysis were further analyzed for between-group difference with paired twotailed $t$ test comparisons. All data were considered significant when between-group differences had $p$ values $<0.05$.

\section{Results}

Treatment of the TG2576 mice with the PKC activator bryostatin-1 was begun 2 months postpartum and continued for 12 weeks to assess efficacy on potential deficits of a slowly progressing $\mathrm{AD}$ pathogenic process that might precede the deposition of amyloid plaques. Treatment of the 5XFAD mice with bryostatin-1, and in separate, more extensive experiments with the PKC $\varepsilon$-specific activator DCP-LA, was administered during the same postpartum interval to assess efficacy on a much more rapidly progressing $\mathrm{AD}$ pathogenic process that included the deposition of amyloid plaques. Effects of both bryostatin-1 and DCP-LA were also studied on the molecular pathogenesis of synaptic loss of proximal dendrites (in stratum radiatum) of pyramidal neurons (their cell bodies located in stratum pyramidale) in the hippocampal CA1 area.

\section{Rapid and significant learning and memory deficits in $\mathrm{Tg} 2576$ mice before amyloid plaque deposition}

For spatial learning and memory studies, Tg2576 mice at 5 months old were trained to find a submerged platform in a water maze pool. At $24 \mathrm{~h}$ after $4 \mathrm{~d}$ of water maze training and learning evaluation, memory retention was assessed with a probe test that allowed mice to find the target area of the removed platform (Fig. $1 A)$. There were significant differences among all experimental groups for learning $\left(F_{(2,446)}=9.962, p<0.001\right.$, ANOVA, days $2-4)$ (Fig. $1 B$ ) and memory $\left(F_{(2,26)}=5.038, p<0.01\right)$ (Fig. $1 C$ ). Comparisons between transgenic and wild-type mice [Tg2576 (5 months) vs wild type (5 months)] showed a significant impairment in learning $\left(F_{(1,251)}=16.596, p<0.001\right.$, ANOVA, days 2-4) (Fig. 

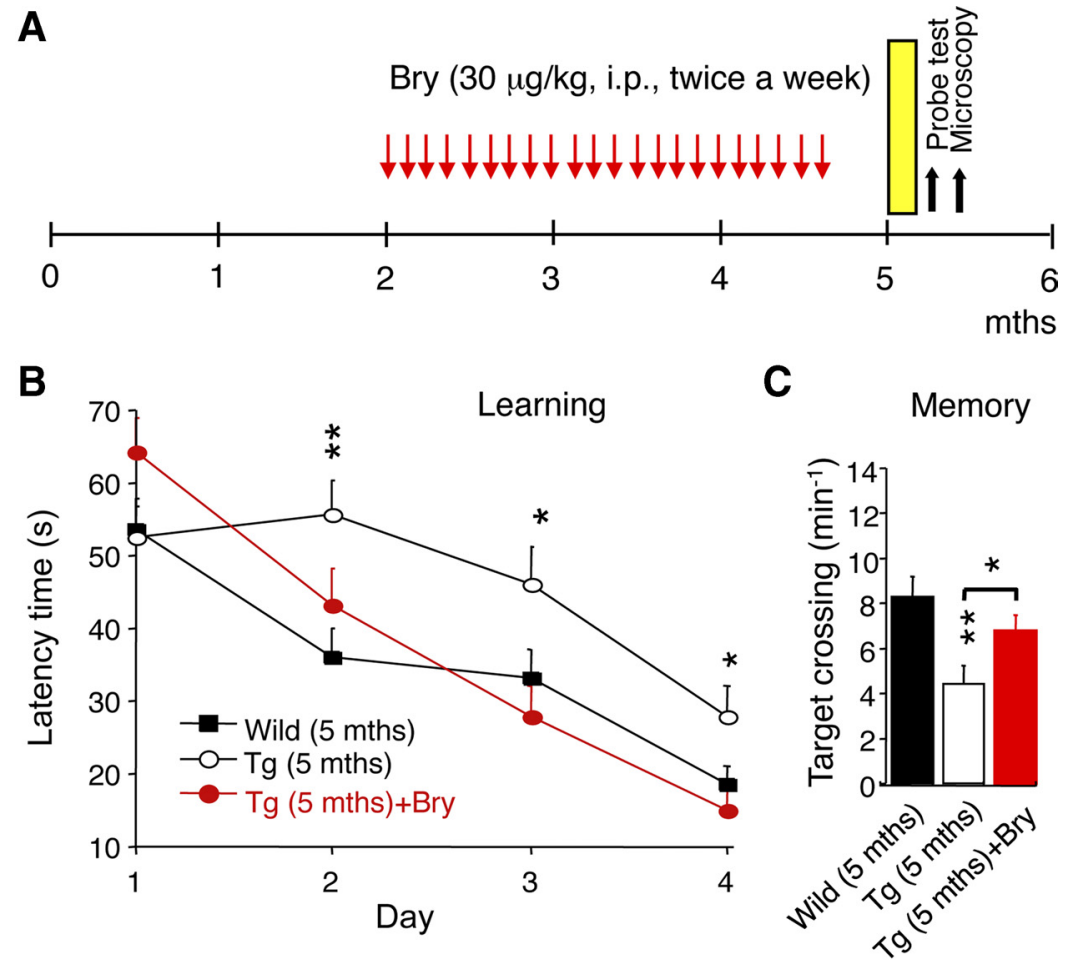

Amyloid plaques in CA1 area

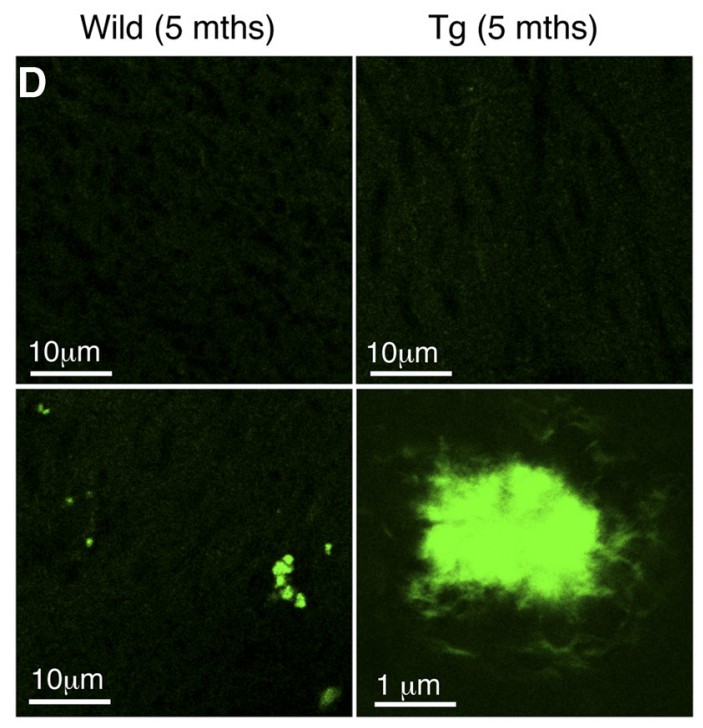

$\operatorname{Tg}(>9$ mths)

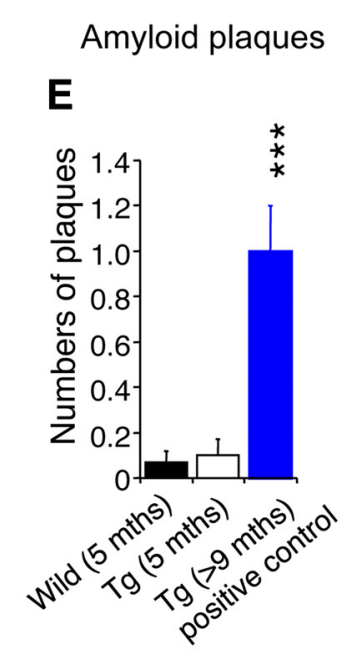

Figure 1. Bryostatin-1 prevents learning and memory deficits before amyloid plaque formation in Tg 2576 mice at 5 months old. $A$, Bryostatin- 1 treatment was started at 8 weeks postpartum and ended $10 \mathrm{~d}$ before water maze training to assess neuroprotective efficacy without the acute cognitive benefits of bryostatin-1. Mice were trained with fewer trials (four trials/day) than previously to better reveal memory deficits. $\boldsymbol{B}, \boldsymbol{C}$, Bryostatin-1 treatment protected against loss of learning acquisition $(\boldsymbol{B})$ and memory recall (C) after water maze training ( $n=7-11$ mice/group). $\boldsymbol{D}$, Confocal microscopy of amyloid plaques stained by Thioflavin-S. $E$, No amyloid plaques were seen in 5 -month old Tg2576 mice. Tg, Tg2576; Bry, bryostatin-1; mths, months. Data are shown as means \pm SEM; ${ }^{*} p<0.05 ;{ }^{* *} p<0.01 ;{ }^{* * *} p<0.001$. See Results for further statistical analyses. For amyloid plaque staining, $n=3-4$ mice; $n=30-40$ sections of CA1 area/group.

$1 B)$ and memory $\left(F_{(2,17)}=9.047, p<0.01\right)($ Fig. $1 C)$ in the spatial water maze task. It should be noted that the training regimen had intentionally been made more difficult to better reveal cognitive deficits.

At $24 \mathrm{~h}$ after the probe test, mice were used for subsequent histochemical and microscopic studies. Amyloid plaques in CA1 stratum radiatum were evaluated by Thioflavin-S staining visualized by confocal microscopy (Fig. $1 D, E$ ). Amyloid plaque deposition was not observed at the age of 5 months old [wild type (5 months) vs Tg2576 (5 months); $p>0.70$ : two-tailed $t$ test (Fig. $1 D, E)]$. Plaques did, however, occur at $>9$ months old $(p<0.001)$ (Fig. $1 D, E)$.

Bryostatin-1 prevents learning and memory deficits before amyloid plaque deposition in $\mathrm{Tg} 2576$ mice

Bryostatin-1, a potent activator of PKC $\varepsilon$ and PKC $\alpha$, was administered $(30 \mu \mathrm{g} / \mathrm{kg}$, i.p., twice a week) to Tg2576 mice at 8 weeks old of age for a 12 week period. Administration of bryostatin-1 was then terminated $10 \mathrm{~d}$ before water maze training to avoid acute cognitive-enhancing effects of bryostatin-1 during subsequent water maze training (Fig. 1A). Bryostatin-1 significantly improved the learning performance of the $\operatorname{Tg} 2576$ mice [Tg2576 (5 months) vs Tg2576 (5 months) plus byrostatin-1: $\left.F_{(1,203)}=12.985, p<0.001\right]$ to the level of the controls (Fig. 1B). Bryostatin-1 also significantly prevented memory deficits in the Tg2576 mice $\left(F_{(1,15)}=4.645, p<0.05\right)($ Fig. $1 C)$.

Increased soluble $\boldsymbol{\beta}$ amyloid protein before amyloid plaque deposition in Tg2576 mice

Changes of soluble $\beta$ amyloid protein- 42 $(\mathrm{A} \beta-42)$ in the pyramidal neurons in the hippocampal CA1 area were analyzed with confocal microscopy and immunohistochemistry (Fig. 2). To identify $A \beta-42$ changes in Tg2576 mice, we used four different antibodies: (1) A $\beta-42$ antibody $6 \mathrm{E} 10$, which recognizes all forms (monomers, oligomers, and fibrils) of $\mathrm{A} \beta-42$ and a great variety of APP metabolites (Cheng et al., 2007); (2) $A \beta-42$ antibody $A 11$, which recognizes $\mathrm{A} \beta-42$ oligomers and other oligomers, such as $\alpha$-synuclein (Kayed et al., 2003); (3) APP antibody (ab15272, Abcam), which recognizes the $\mathrm{N}$-terminal portion of the APP (this antibody does not recognize $\mathrm{A} \beta$-42); and (4) $\alpha$-synuclein antibody (Santa Cruz Biotechnology), which recognizes $\alpha$-synuclein.

In summary, the results with these four antibodies (as described below) demonstrated that increased $\mathrm{A} \beta-42$, as recognized both by the $6 \mathrm{E} 10$ and A11 antibodies, cannot be explained by increased levels of either APP or $\alpha$-synuclein.

There were significant differences among experimental groups for the anti-A $\beta$-42 antibody $6 \mathrm{E} 10\left(F_{(2,429)}=20.799, p<\right.$ 0.001 ) (Fig. $2 A, B)$. At 5 months old, Tg2576 mice showed an increase in fluorescence intensity in the extranuclear cytoplasmic space surrounding the CA1 nuclei for the 6E10 antibody $(p<$ 
0.001; two-tailed $t$ test) (Fig. $2 A, B$ ). With the anti-APP antibody, however, there was decreased APP fluorescence intensity within the cell bodies of CA1 pyramidal neurons in the Tg2576 mice at 5 months old $\left(F_{(2,602)}=16.114, p<0.001\right)$ (Fig. $2 D, E$ ) and no increase in the extranuclear cytoplasmic space surrounding the CA1 nuclei. These results suggest, therefore, that the increased fluorescence intensity of $6 \mathrm{E} 10$ antibody in the cell bodies of the CA1 neurons was caused by an increase in A $\beta-42$ derived from APP catabolism but not from increased levels of APP. A previous study, which made whole brain measurements with immunoblots, showed an increase in APP levels in these Tg2576 mice (which overexpressed the Swedish mutation of the APP gene) (Kawarabayashi et al., 2001). The differences between the results of this previous study and our present results could be due to the heterogeneous distribution of APP (to which immunochemical analyses but not whole brain gels would be sensitive) within brain regions and/or cell compartments of the hippocampus. In any case, the changes of APP immunohistochemistry images in Figure 2D are so clearly different from the changes of the $6 \mathrm{E} 10$ antibody immunohistochemistry (Fig. 2A) that an increase of $A \beta-42$, as measured by the $6 \mathrm{E} 10$ immunofluorescence, cannot be explained by an increase of APP.

Consistent with these results with the $6 \mathrm{E} 10$ antibody, $\mathrm{A} \beta-42$ oligomers were also increased in $\operatorname{Tg} 2576$ mice as evidenced by increased staining using the A11 antibody, which binds to oligomers of several peptides, including $\mathrm{A} \beta-42$, insulin, and synuclein. The increased staining was not due to a generalized increase in oligomerized peptides, because $\alpha$-synuclein staining was not affected. There was a significant difference among experimental groups $\left(F_{(2,429)}=24.951, p<0.001\right)$ (Fig. $\left.2 A, C\right)$ for the A11 antibody extranuclear intracytoplasmic fluorescence for the CA1 pyramidal cells, but no significant difference among experimental groups was observed in the same cytoplasmic compartments for the fluorescence of the anti- $\alpha$ synuclein antibody $\left(F_{(2,602)}=1.950, p=0.143\right)($ Fig. $2 D, F)$, These latter results suggest that the A11 antibody immunohistochemistry reflects $\mathrm{A} \beta-42$ oligomer levels but not levels of $\alpha$-synuclein (which has been implicated in Alzheimer's disease involving mitochondrial dysfunction and apoptotic cell death) (Suh and Checler, 2002; Devi and Anandatheerthavarada, 2010).

Thus, the only conclusion consistent with all of the above results with the four different antibody protocols is that $A \beta-42$ increased within the cell bodies of the CA1 neurons of the Tg2576 mice. Such increased levels of soluble $\mathrm{A} \beta-42$ protein (and their normalization by the bryostatin-1 treatment described below) within the hiparea/group.
A $\quad$ CA1 pyramidal neurons
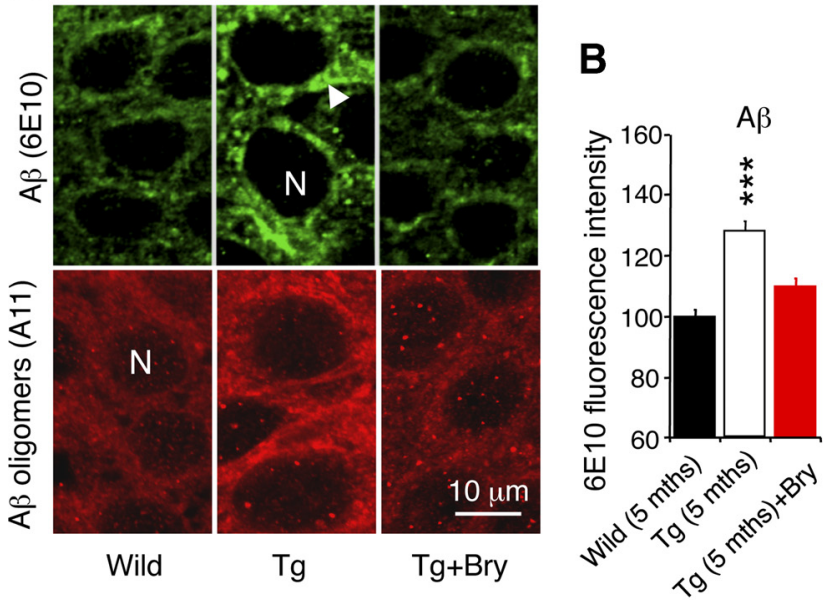

C

D CA1 pyramidal neurons
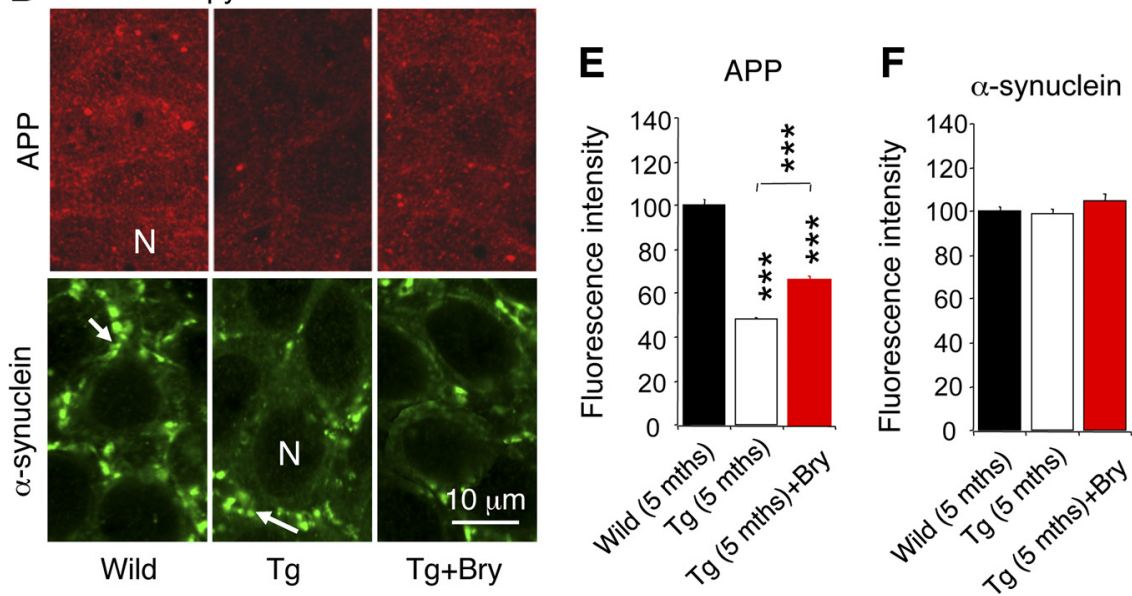

Fryostatin-1 prevents soluble $A \beta$ elevation before amyloid plaque formation in Tg2576 mice at 5 months old. $\boldsymbol{A}$ A11 antibody against $A \beta$ oligomers (bottom). The 6E10 antibody is known to cross react with APP metabolites, and the A11 ntibody is known to cross react with oligomers of $\alpha$-synuclein and other proteins (see text). N, Nucleus; arrowhead, neuronal cell mice. C, Quantitative analyses of the A11 antibody immunofluorescence in the wild-type, $\operatorname{Tg} 2576$, and bryostatin-treated mice. D Confocal microscopy and immunohistochemistry of the APP antibody and the $\alpha$-synuclein antibody. $\alpha$-Synuclein was found $\alpha$-synuclein in the $\operatorname{Tg} 2576$ mice. $\boldsymbol{E}$, Quantitative analyses of the APP antibody immunofluorescence in the wild-type, $\operatorname{Tg} 2576$, and ostatin-treated mice. $\boldsymbol{F}$, Quantitative analyses of the $\alpha$-synuclein antibody immunofluorescence in the wild-type, $\operatorname{Tg} 2576$, and bryostatin-treated mice. Increased fluorescence intensity of 6 E10 antibody $(\boldsymbol{B})$ and decreased APP $(\boldsymbol{E})$ indicate an increase in A $\beta$ in pyramidal neurons in the hippocampal ( $A 1$ area of $\operatorname{Tg} 2576$ mice at 5 months old. Increased $A 11$ antibody $(C)$ and no change of the bryostatin-1; mths, months. Data are shown as means \pm SEM; ${ }^{* * *} p<0.001 . n=3$ or 4 mice; $n=30-40$ sections of CA1

pocampal CA1 pyramidal neurons in Tg2576 mice at 5 months old may contribute to the cognitive (see Rapid and significant learning and memory deficits in Tg2576 mice before amyloid plaque deposition) and possibly synaptic (see Early synaptic loss (per unit volume) in proximal dendrites of CA1 pyramidal neurons before amyloid plaque deposition in $\operatorname{Tg} 2576$ mice) deficits (and their normalization) that we observed.

Increased soluble $\boldsymbol{\beta}$ amyloid protein per unit volume of stratum radiatum of hippocampal CA1 area before amyloid plaque deposition in $\mathrm{Tg} 2576$ mice

These results for the CA1 neuron cell bodies in the stratum pyramidale closely paralleled similar analyses made in the stratum 

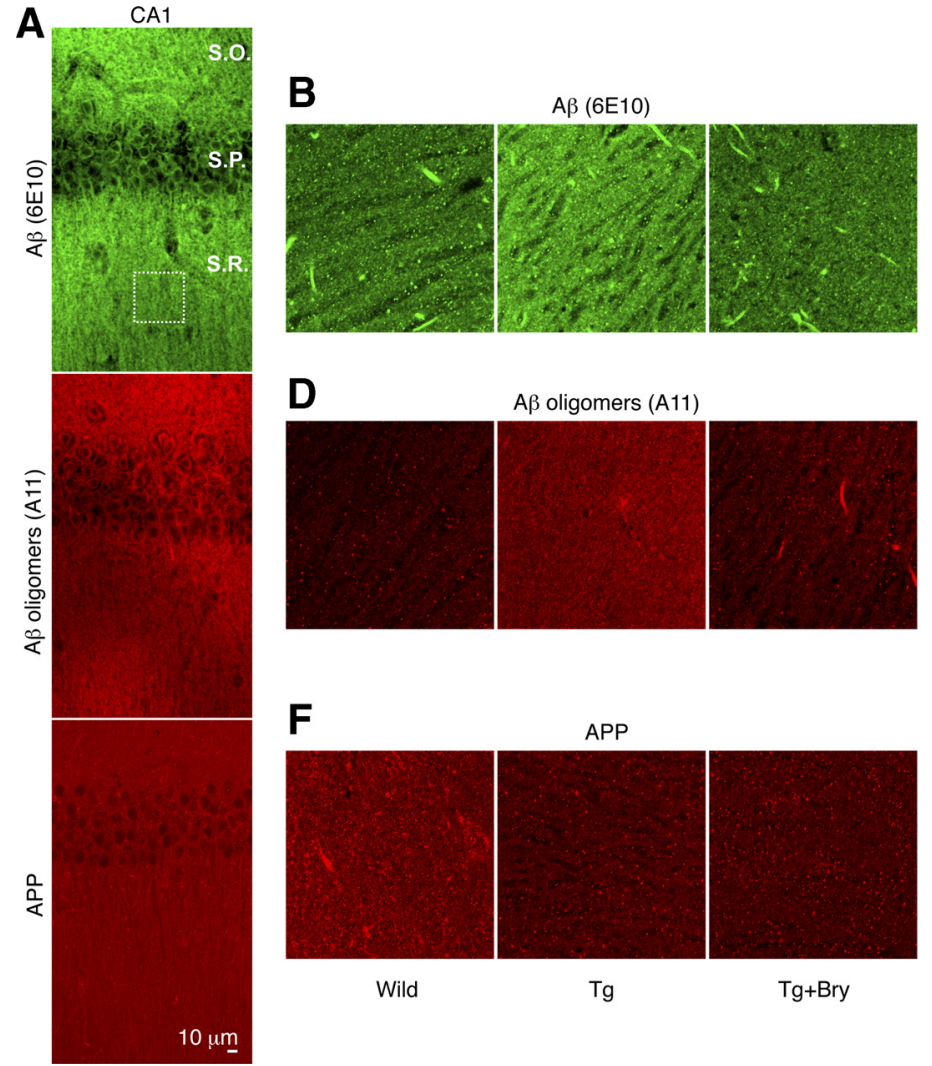

$A \beta$ oligomers (A11)
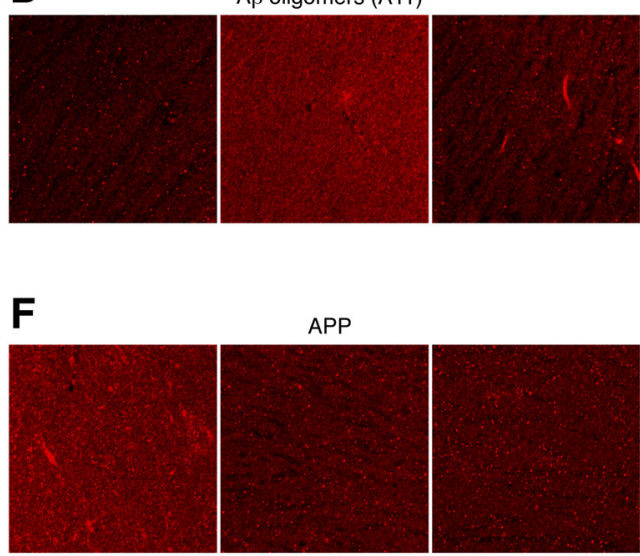

Wild

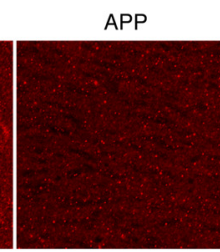

$\mathrm{Tg}$
Figure 3. Bryostatin-1 prevents soluble $A \beta$ elevation in stratum radiatum of the hippocampal $C A 1$ area before amyloid plaque formation in Tg2576 mice at 5 months old. A, Confocal microscopy (lower magnification) of the hippocampal CA1 area immunostained with the 6E10, A11, and anti-APP antibodies, as used in Figure 2. S.0., Stratum oriens; S.P., stratum pyramidale; S.R., stratum radiatum. $\boldsymbol{B}-\mathbf{G}$, Dashed line square represents the enlargement of random areas for confocal imaging in stratum radiatum used for the quantification of the $6 \operatorname{E10}(\boldsymbol{B}, \boldsymbol{C}), \operatorname{A11}(\boldsymbol{D}, \boldsymbol{E})$, and $\operatorname{APP}(\boldsymbol{F}, \boldsymbol{G})$ immunohistochemistry. Otherwise, as in Figure 2. The findings shown here for the stratum radiatum closely paralleled the findings for the stratum pyramidale shown in Figure 2 . $\mathrm{Tg}$, Tg2576; Bry, bryostatin-1; mths, months. Data are shown as means \pm SEM; ${ }^{* *} p<0.01 ;{ }^{* *} p<0.001 . n=3$ to 4 mice; $n=$ $30-40$ sections of CA1 area/group.

radiatum (Fig. 3) (see below) where the CA 1 proximal apical dendrites, dendritic spines, and presynaptic axonal boutons are located. Namely, the $\mathrm{A} \beta-42$ antibody fluorescence (6E10 and A11) showed an increase in the TG2576 versus the wild-type, whereas the APP antibody fluorescence showed a decrease in the TG2576 mice. There were significant differences among experiment groups for $6 \mathrm{E} 10\left(F_{(2,89)}=4.268, p<0.01\right)($ Fig. $3 B, C), \mathrm{A} 11$ $\left(F_{(2,89)}=6.601, p<0.01\right)$ (Fig. $\left.3 D, E\right)$, and anti-APP $\left(F_{(2,74)}=\right.$ 14.901, $p<0.001$ ) (Fig. $3 F, G$ ) antibodies. Soluble A $\beta-42$ was increased as measured with $6 \mathrm{E} 10$ and A11 antibodies $(p<0.01)$ (Fig. 3C,E), whereas APP levels were decreased $(p<0.001)$ (Fig. $3 G)$ in dendrites and/or surrounding tissue structures of CA1 pyramidal neurons of $\operatorname{Tg} 2576$ mice. Finally, sections taken at lower magnification (Fig. 3A) provided visualization of a similar pattern of fluorescence results across the entire CA1 area.

\section{Bryostatin-1 prevents the soluble $\boldsymbol{\beta}$ amyloid protein increase} before amyloid plaque deposition in Tg2576 mice

Bryostatin treatment for 12 weeks prevented the increase in soluble $\mathrm{A} \beta-42$ protein in the hippocampal CA1 pyramidal neurons of these $\mathrm{Tg} 2576$ mice both in the extranuclear cell body compartment $(p<0.01)$ (Fig. $2 B, E)$ and in dendrites $(p<0.01)$ (Fig. $3 \mathrm{C}, E)$. Bryostatin also significantly prevented the decrease in APP in the extranuclear cytoplasmic compartments (Fig. 2E) and the dendrites (Fig. 3G), although the APP levels were still signifi-

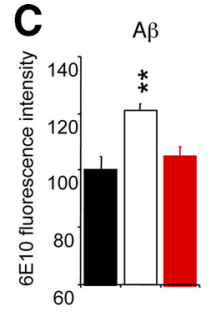

\section{E}

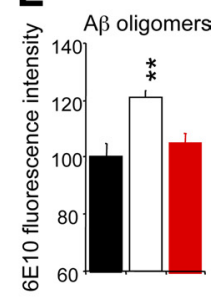

G

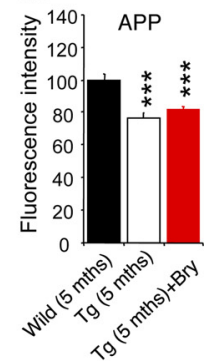

cantly lower than in the wild-type control. These results are consistent with the interpretation that the bryostatin-1-induced prevention of the increase in soluble $\mathrm{A} \beta-42$ protein could contribute to the observed bryostatin-1-induced prevention of the deficits of learning and memory in the Tg2576 mice.

\section{Reduction of PKC $\alpha$ and PKC $\varepsilon$ before amyloid plaque deposition in Tg2576 mice}

Previous studies have implicated PKC $\varepsilon$ in synaptogenesis with in vitro culture analyses (Hama et al., 2004) and PKC $\alpha$ and $\varepsilon$ in learning and memory in vivo (Hongpaisan and Alkon, 2007). We therefore next measured levels of PKC $\varepsilon$ located specifically in presynaptic compartments (Fig. 4A-E) and PKC $\alpha$ in cellular compartments (Fig. $4 F, G$ ) in the $\mathrm{AD}$ transgenic Tg2576 and control wild-type mouse brains at 5 months old, using immunohistochemistry visualized by confocal microscopy.

In the hippocampal CA3 area, a significant difference among the experimental groups of PKC $\varepsilon$ levels was found $\left(F_{(2,79)}=\right.$ 38.564, $p<0.001$ ) (Fig. $4 B$ ) in the mossy fibers consisting of axons from the granule cells of the dentate gyrus that terminate on neurons in the CA3 area. Post hoc testing showed that $\mathrm{PKC} \varepsilon$ levels in the mossy fibers were reduced $(p<0.001)$ (Fig. $4 A, B)$ in the $\operatorname{Tg} 2576$ mice.

In the CA1 stratum radiatum, the numbers of presynaptic axonal boutons with and without $\mathrm{PKC} \varepsilon$ (per unit volume of hippocampal CA1 area) were studied by confocal microscopy and double immunohistochemistry of PKC $\varepsilon$ (green fluorescence) and the axonal bouton marker synaptophysin (red fluorescence) at the level of single axonal boutons (Fig. 4C). Approximately two-thirds ( $64 \pm 5 \%$ ) (Fig. $4 E$ ) of the number of all axonal boutons in the CA1 area contained PKC $\varepsilon$ in wild-type mice (Fig. $4 C$, green + red $=$ yellow). A significant difference among experimental groups was seen in the number of all presynaptic axonal boutons (red; $F_{(3,167)}=9.763, p<0.001$ ) (Fig. $4 C, D)$ and in the number of PKC $\varepsilon$-containing axonal boutons (yellow; $F_{(2,83)}=10.924, p<0.001$ ) (Fig. $4 C, E$ ). Detailed statistical analysis demonstrated a loss in the total number of axonal boutons (with and without PKC $\varepsilon$-containing boutons taken together) $[p<0.001$ (Fig 4D); Tg2576 (5 months) vs wild type (5 months)] in the area of the CA1 neurons. These boutons presumably arose from the Schaeffer collateral fibers that are collateral branches of axons from CA3 neurons that synapse on CA1 neurons. A significant loss of PKC $\varepsilon$-containing axonal boutons in the hippocampal CA1 stratum radiatum was also observed $(p<$ 0.001) (Fig. 4E).

PKC $\alpha$ has previously been shown to be expressed in the pyramidal cell bodies of CA1 hippocampus (Sieber et al., 1998; Hongpaisan et al., 2004; Hongpaisan and Alkon, 2007). Because PKC $\alpha$ activates nuclear export of the mRNA-stabilizing protein ELAV, which moves into dendrites and in turn promotes protein 
synthesis, synaptogenesis, and memory (Hongpaisan and Alkon, 2007), PKC $\alpha$ content in the bodies of the pyramidal neurons in hippocampal CA1 stratum pyramidale was also studied in Tg2576 mice. A significant difference among groups for PKC $\alpha$ content was found $\left(F_{(2,626)}=\right.$ $33.118, p<0.001$ ) (Fig. $4 F, G)$. These results suggest that an increase in soluble A $\beta-42$ protein, before amyloid plaque formation (Figs. 2, 3), suppressed the expression of PKC $\varepsilon$ and $\alpha$ in the hippocampal neurons (Fig. 4).

Bryostatin-1 prevents the reduction of PKC $\alpha$ and PKC $\varepsilon$ before amyloid plaque deposition in $\mathrm{Tg} 2576$ mice The decrease in PKC $\varepsilon$ levels within the presynaptic mossy fibers, synapsing with the CA3 neurons, was prevented by bryostatin-1 $(p<0.001)$ (Fig. $4 A, B)$. Bryostain-1 treatment entirely prevented the loss of axonal boutons $(p<0.001)$ (Fig. $4 C, D$ ). Bryostain-1 also restored the number of PKC $\varepsilon$-containing axonal boutons $(p<0.05)$ (Fig. $4 C, E$ ) and prevented the decrease of PKC $\alpha$ immunofluorescence in the cell bodies of the hippocampal CA1 pyramidal neurons $(p<0.001)$ (Fig. $4 F, G$ ). These results suggest that the reduction of soluble $\mathrm{A} \beta$ protein by bryostatin-1 (Figs. 2, 3) prevented the loss of PKC $\varepsilon$ and $\alpha$ levels. It should be noted that the bryostatin-1-evoked increases in the levels of PKC $\varepsilon(p<0.001)$ (Fig. 4B) and PKC $\alpha$ significantly exceeded the control levels $(p<0.05)$ (Fig. $4 G)$, indicating increased synthesis of these isozymes due to PKC activation.

Early synaptic loss (per unit volume) in proximal dendrites of CA1 pyramidal neurons before amyloid plaque deposition in $\mathrm{Tg} 2576$ mice

Because memory loss in vivo is closely associated with synaptic loss in the $\mathrm{AD}$ brain (Sze et al., 1997) at autopsy, we quantified synaptic numbers and structures in the hippocampal CA1 stratum radiatum, which contains mainly proximal dendritic shafts of CA1 pyramidal neurons, with conventional and electron microscopic techniques. Immunohistochemical detection of the dendritic spines by using spinophilin as the spine marker (visualized with a confocal microscope) (Fig. $5 A$ ) revealed a significant difference among experimental groups $\left(F_{(2,99)}=9.050, p<\right.$ 0.001) (Fig. 5B). Tg2576 mice at 5 months old showed a reduction in the total number of dendritic spines $(p<0.001)$. This reduction was not the result of cell death at this age, because there was no difference among groups in the number of pyramidal neurons in the CA1 area (cell viability test; $F_{(2,31)}=6.692, p=$ 0.64) (Fig. 5C) and no increase in apoptotic cell death (Fig. 5D). DiI staining visualized with a confocal microscope and quantified with a double blind protocol (unknown treatment and subject identifica-
$\mathrm{PKC} \varepsilon$
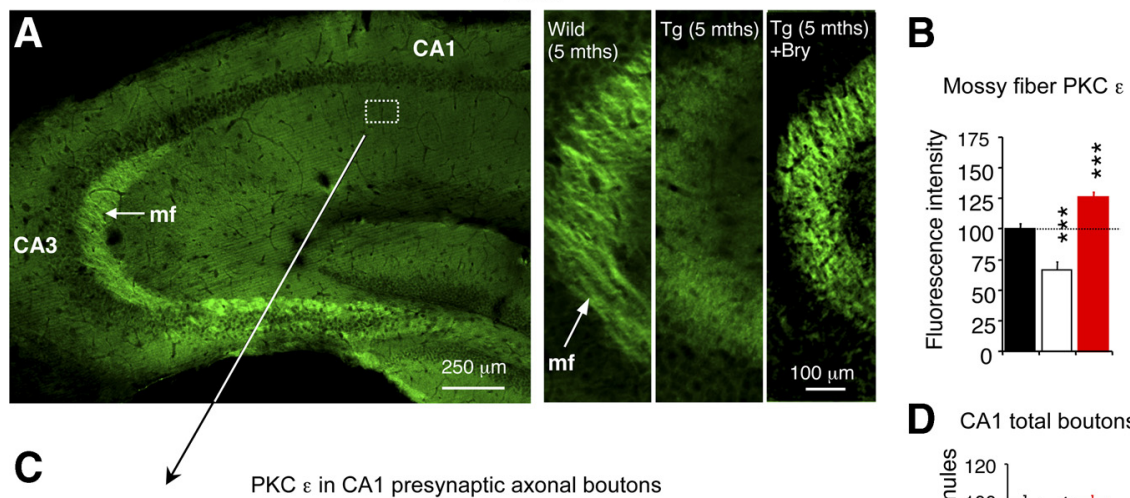

D CA1 total boutons

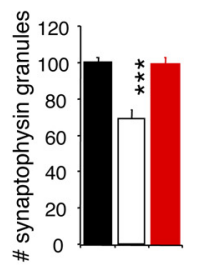

E
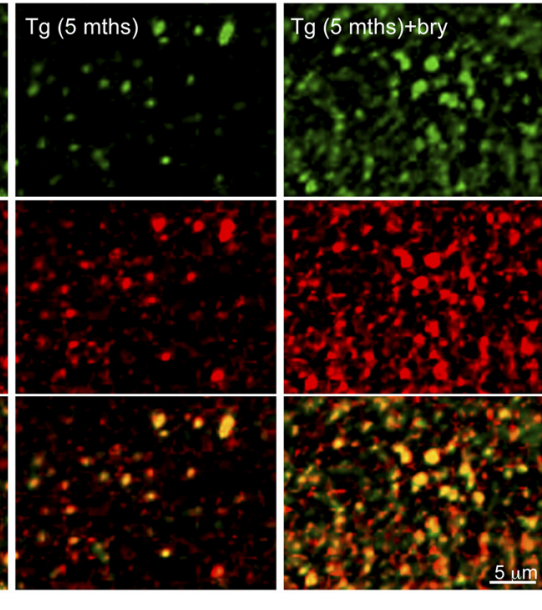

CA1 PKC boutons

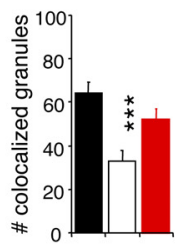

G $\quad$ CA1 PKC $\alpha$

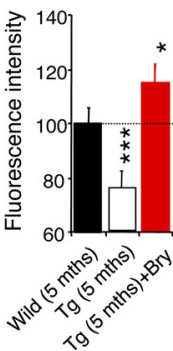

Figure 4. Bryostatin-1 prevents a decrease in PKC expression in hippocampi of Tg2576 mice at 5 months old. Confocal microscopy and immunohistochemistry ( $n=3$ to 4 mice; $n=30-40$ sections of the CA1 area or 102-188 neurons/group) of PKC $\varepsilon(\boldsymbol{A}-\boldsymbol{E})$ and PKC $\alpha(\boldsymbol{F}$, $\boldsymbol{G}$. $\boldsymbol{A}-\boldsymbol{D}$, Bryostatin-1 prevented reduction of and significantly increased the PKC $\varepsilon$ immunofluorescence in the mossy fibers $(\mathrm{mf})(\boldsymbol{A}, \boldsymbol{B})$ and prevented reduction of the total number of presynaptic axonal boutons (synaptophysin granules) in the CA1 hippocampus area $(\boldsymbol{C}, \boldsymbol{D})$. $\boldsymbol{C}$, The left panel, labeled Wild (5 mths), was approximately enlarged from the white dashed rectangle area in $\boldsymbol{A}$. Red, Axonal boutons (synaptophysin); green, PKC $\varepsilon$; yellow, colocalization of PKC $\varepsilon$ in axonal boutons. Green PKC $\varepsilon$ fluorescence in middle panel is obscured by bryostatin-1 treatment $(\boldsymbol{C}, \boldsymbol{E})$. Bryostatin-1 also protected the suppression of PKC $\alpha$ in CA1 pyramidal neurons $(\boldsymbol{F}, \boldsymbol{G})$. Tg, Tg2576; Bry, bryostatin-1; mths, months. Data are shown as means \pm SEM; ${ }^{*} p<0.05 ;{ }^{* * *} p<0.001$.

tion) and by three-dimensional reconstruction showed a significant difference among experimental groups for the total numbers of dendritic spines $\left(F_{(2,46)}=4.055, p<0.05\right)$ (Fig. 5E,F) and mushroom-shaped dendritic spines $\left(F_{(2,46)}=6.467, p<0.01\right)$ (Fig. $5 E, G)$ on dendritic shafts. The Tg2576 mice at 5 months old had a significant decrease in the total number of dendritic spines $(p<$ 0.001 ) (Fig. 5E,F) and the number of mushroom-shaped dendritic spines $(p<0.001)$ (Fig. $5 E, G)$.

Because one dendritic spine can form more than one synapse, it is possible that increased synaptic density per spine might compensate for reduced dendritic spine density. The numbers and structures of synapses were, therefore, directly studied by electron microscopy with double-blind analysis. There was a signifi- 
A The dendritic spine-specific protein spinophilin
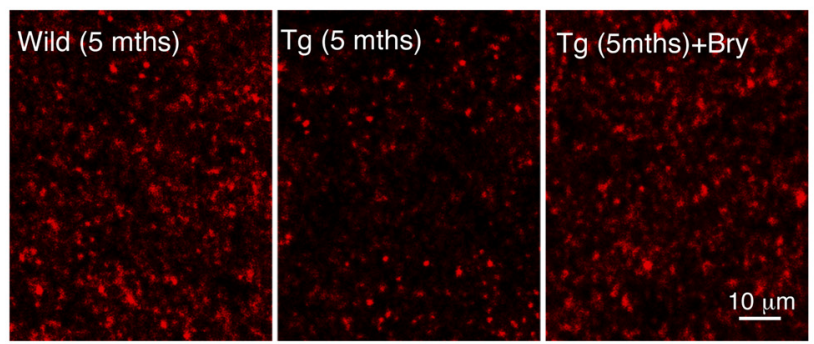

E CA1 proximal dendrites

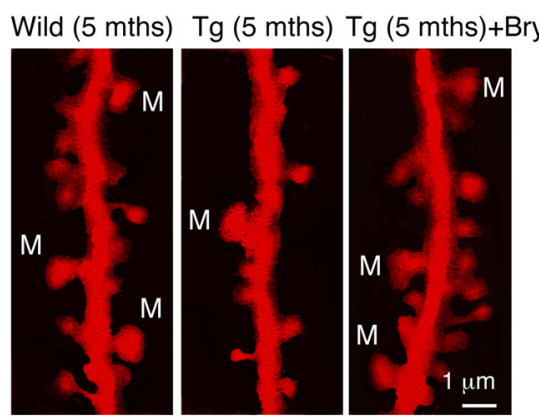

B

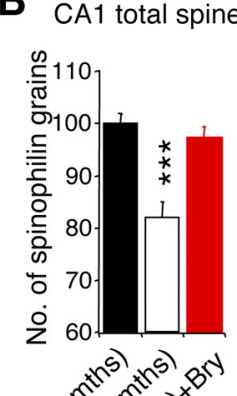

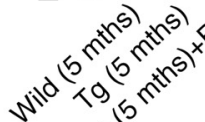

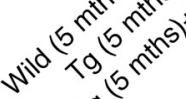

ro
C

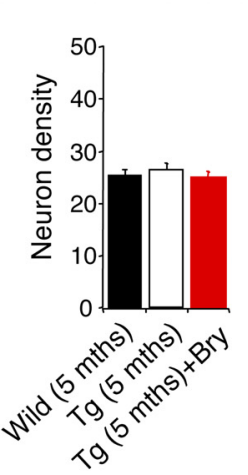

D Apoptotic cells

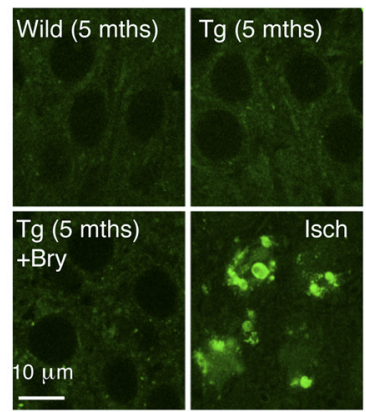

G

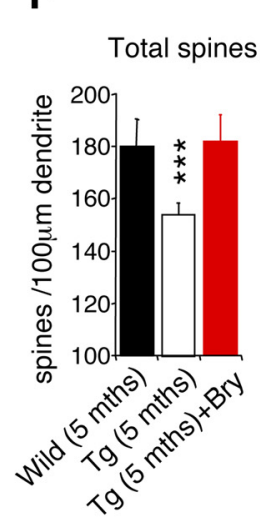

\section{H}

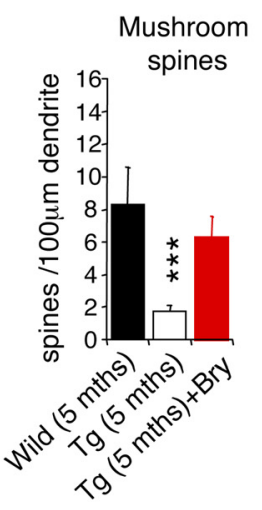

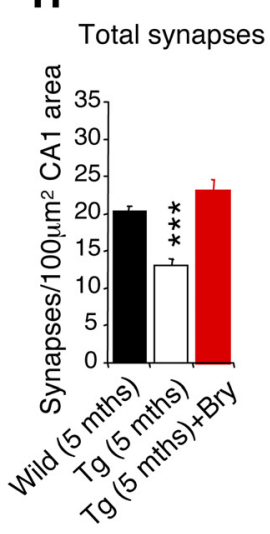

$$
\text { I }
$$

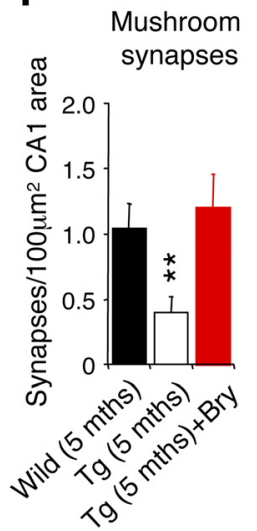

\section{J CA1 synapses}
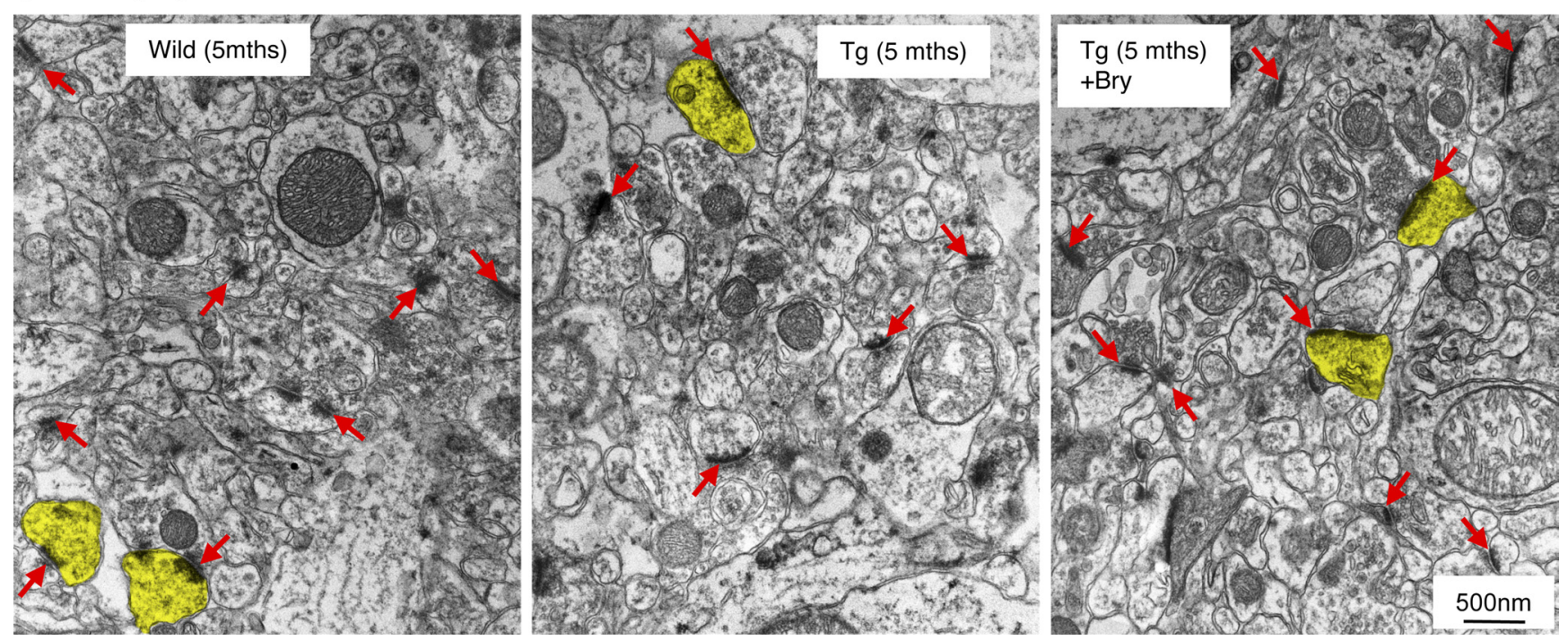

Figure 5. Bryostatin-1 protected Tg2576 mice against the loss of postsynaptic dendritic spines and synapses in the hippocampal CA1 area. $A$, Confocal microscopy and immunohistochemistry of the dendritic spine-specific protein spinophilin $(n=3-4$ mice; $n=30-40$ sections of the $C A 1$ area/group). $\boldsymbol{B}$, Reduction of the number of dendritic spines. $\boldsymbol{C}, \boldsymbol{D}$, No changes of the density of pyramidal neuron nuclei $(\boldsymbol{C} ; n=$ 3 mice; $n=12$ sections of CA1 area/group) and apoptotic cell death by TUNEL staining ( $\boldsymbol{D} ; n=3$ mice; $n=12$ hippocampal slices/group) were observed using postischemic (Isch) hippocampus for positive control staining. $E$, Confocal microscopy of dendritic spine density on dendritic shaft stained by Dil ( $n=3$ mice; $n=12-20$ dendritic shafts/group); M, Mushroom spine. $F$, The reduction of total dendritic spines (with spinophilin) in $A$ and $B$ is the consequence of dendritic spine loss (Dil confocal microscopy) in an individual dendritic shaft/neuron rather than neuronal cell death. $G$, Loss of mushroom spine formation (Dil confocal microscopy) in Tg2576 mice. $\boldsymbol{H}-J$, Electron microscopy ( $n=3$ mice; $n=25-35$ electron micrographs/group; yellow highlight, dendritic spine and associated mushroom synapse; red arrow, synapse) confirmed changes of total number of synapses $(\boldsymbol{H})$ (thin, stubby, and mushroom spines taken together) as indicated in $J$ by red arrows; changes of only mushroom spine synapses $(\boldsymbol{I})$ as indicated in $\boldsymbol{J}$ by yellow highlights were parallel to changes of dendritic spines. Tg, Tg2576, Bry, Bryostatin-1; mths, months. Data are shown as means \pm SEM ${ }^{* *} p<0.01 ;{ }^{* * *} p<0.001$.

cant difference among groups for the total (thin, stubby, and mushroom spine synapses together) number of synapses $\left(F_{(2,85)}=\right.$ $24.647, p<0.001)$ (Fig. $5 \mathrm{H}, J)$ and for mushroom spine synapses $\left(F_{(2,85)}=6.687, p<0.01\right)($ Fig. $5 I, J)$. Electron microscopy with a double blind analysis showed a significant decrease in the total number of synapses $\left(F_{(2,85)}=24.647, p<0.001\right)$ (Fig. $\left.5 H\right)$ and mushroom spine synapses $\left(F_{(2,85)}=6.687, p<0.01\right)$ (Fig. $\left.5 I\right)$ in the hippocampal CA1 area of Tg2576 mice. The results in Figure $3 \mathrm{im}$ - 
plied, therefore, that the loss of dendritic spines and synapses was not caused by cell death but rather by the reduction of dendritic spines in each individual neuron/dendritic shaft in Tg2576 mice at 5 months old before amyloid plaque formation.

Bryostatin-1 prevents early synaptic loss (per unit volume) in proximal dendrites of hippocampal CA1 area in Tg2576 mice

The bryostatin-1 treatment prevented the loss of dendritic spines $(p<0.01)$ (Fig. $5 B$ ), including the total number of dendritic spines on an individual dendritic shaft $(p<0.001)$ (Fig. 5F). Bryostatin-1 also prevented the loss of mushroom spines $(p<0.01)$ (Fig. $5 G)$, mushroom spine synapses $(p<0.001)$ (Fig. 5I), and loss of the total number of synapses $(p<$ 0.01 ) (Fig. 5H) in Tg2576 mice. Therefore, our results suggest that the prevention of PKC $\varepsilon$ and PKC $\alpha$ reduction, by bryostatin-1, inhibited the loss of mushroom spine formation, deficits of their synaptogenesis, and associated memory deficits in Tg2576 mice.

Bryostatin-1 inhibits the suppression of brain-derived neurotrophic factor that is associated with synaptic loss before amyloid plaque deposition

Given this AD transgenic loss of synaptic number and its restoration by PKC activators, we examined two important regulators of synaptogenesis, BDNF and astrocytic activity. BDNF is activated by PKC through the ELAV/HuD mRNA stabilizing protein pathway (Pascale et al., 2005). Another pathway that impacts on synaptogenesis involves local contact between dendrites and astrocytes mediated by cell-cell contact through integrin receptors. These receptors activate phospholipase $\mathrm{A}_{2}$, which produces arachidonic acid, a PKC activator (Hama et al., 2004).

BDNF has been previously shown to be expressed in the cytoplasm and nuclei of CA1 cell bodies of pyramidal neurons (Wetmore et al., 1991; Wetmore and Olson, 1993; Nitta et al., 1997). Figure $6 \mathrm{~A}$ shows BDNF immunofluorescence in the cytoplasm and punctuate (or clumps) fluorescent particles in the nuclei of CA1 neurons; these results were also observed by others [Wetmore et al. (1991), their Fig. 3B]. There was a significant difference among groups for BDNF expression in cell bodies $\left(F_{(2,430)}=\right.$ 36.593, $p<0.001)$ (Fig. $6 A, B)$ and dendrites $\left(F_{(2,71)}=9.067, p<\right.$ 0.001 ) (Fig. $6 C, D$ ) within the hippocampal CA1 area. Bryostatin-1 prevented the reduction of BDNF that occurred in the Tg2576 mice $(p<0.01)$ (Fig. $6 B, D)$. By contrast, no significant difference among experimental groups was found for the numbers of astrocytes $\left(F_{(2,77)}=0.527, p=0.593\right)$ (Fig. 6E,F). However, a tendency toward reduced number of the astrocytes was observed in Tg2576 mice at 5 months old (Fig. 6F) (Tg2576 vs wild type).

These results indicate that the suppression of BDNF is a reasonable molecular target of reduced PKC $\varepsilon$ and $\mathrm{PKC} \alpha$ expression that could contribute to the reduction of presynaptic axonal bou- tons and postsynaptic dendritic spines, as well as synaptic loss during early stage $\mathrm{AD}$.

\section{Bryostatin-1 prevents learning and memory deficits after} amyloid plaque deposition in 5XFAD mice

Using similar protocols (Fig. 1A), treatments were started at 2 months old when 5XFAD mice had been previously shown to already develop robust amyloid deposits (Oakley et al., 2006). There were significant learning differences among the four groups $\left(F_{(3,611)}=25.472, p<0.001\right)$ (Fig. $\left.7 A\right)$, indicating different learning between the groups. Bryostatin-1 significantly improved the spatial learning of the 5XFAD mice (5XFAD plus vehicle vs 5XFAD plus bryostatin-1: $\left.F_{(1,323)}=66.434, p<0.001\right)$ (Fig. 7A) to the level of the controls (wild type plus vehicle vs $5 X F A D$ plus bryostatin-1: $\left.F_{(1,287)}=1.455, p>0.05\right)$. There were also significant differences in the target quadrant ratio among the groups $\left(F_{(3,31)}=3.428, p<0.05\right)$, indicating differences in the spatial memory among the groups. Detailed analysis revealed that bryostatin-1 treatment in the transgenic mice significantly improved the memory recall compared with that of the transgenic mice without the treatment $\left(F_{(1,15)}=6.466, p<0.05\right)$ (Fig. 7B).

\section{Activation of PKC $\varepsilon$ alone by DCP-LA protects against memory deficits in 5XFAD mice}

Previous studies in two different laboratories demonstrated that the compound DCP-LA is an activator that is specific for the $\varepsilon$ 

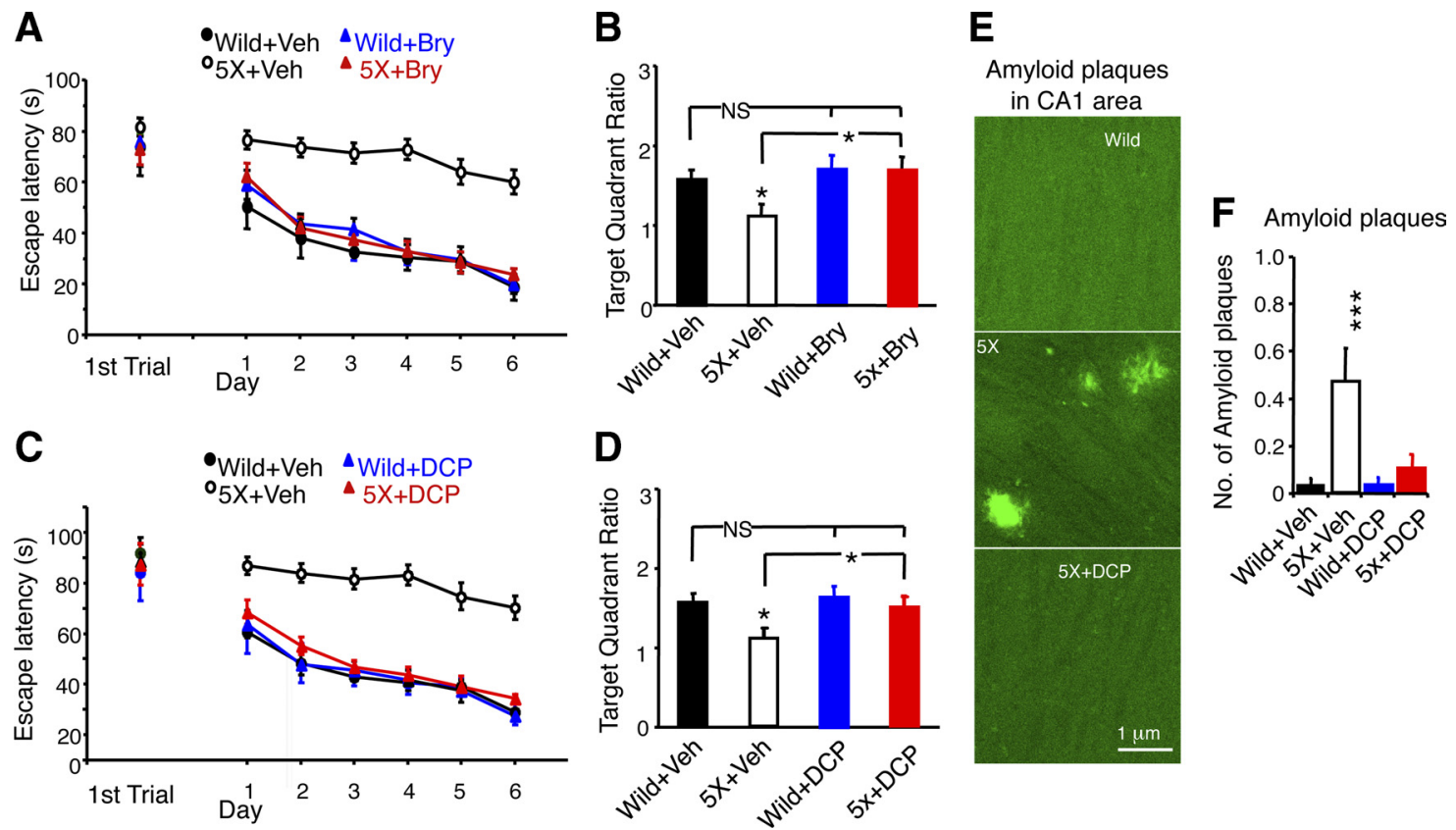

Figure 7. Bryostatin-1 and the PKC $\varepsilon$-specific activator DCP-LA prevent learning and memory deficits and amyloid plaque formation. $A, C$, Spatial water maze learning of mice over training trials. Data are shown as means $\pm S E M$, using the daily three trials as a block. The result of the first training trial showed no significant difference between groups for bryostatin-1 $\left(\boldsymbol{A}, F_{(3,35)}=3.661 ; p>\right.$ $0.05)$ and for DCP-LA $\left(C, F_{(3,35)}=0.178 ; p>0.05\right)$ treatment, whereas successive training trials revealed highly significant differences between bryostatin-1-treated or DCP-LA-treated groups vs other groups (see text for statistical analysis). $\boldsymbol{B}, \boldsymbol{D}$, Spatial water maze memory as measured by target quadrant ratios (dividing the target quadrant distance by the average of the nontarget quadrant values) during the probe test. $E, F$, Confocal microscopy of amyloid plaques stained by Thioflavin-S ( $n=3$ mice; $n=30$ sections of the CA1 area/group). $5 X, 5 X F A D$ transgenic mice; Bry, bryostatin-1; DCP, DCP-LA; Veh, vehicle. Data are shown as means \pm SEM; ${ }^{*} p \leq 0.05 ;{ }^{* * *} p<0.001 ; \mathrm{NS}, p \geq 0.05$.

isozyme of PKC (Kanno et al., 2006; Nelson et al., 2009). To determine whether activation of the $\varepsilon$ isozyme alone was sufficient to produce protective effects in transgenic mice similar to those produced by bryostatin-1, we therefore administered DCP-LA 2 months postpartum in the 5XFAD transgenic mice. Significant differences among experimental groups were observed for learning acquisition $\left(F_{(3,647)}=27.592, p<0.001\right)$ (Fig. $\left.7 C\right)$ and memory retention $\left(F_{(3,35)}=3.661, p<0.05\right)$ (Fig. $\left.7 D\right)$. Subsequent statistical analysis found that enhancement effects on learning and memory were observed after treatment with DCP-LA (learning between 5 XFAD plus vehicle vs 5 XFAD plus DCP-LA: $F_{(1,324)}=$ 158.72, $p<0.001$; memory recall between 5 XFAD plus vehicle vs 5XFAD plus DCP-LA: $F_{(1,18)}=4.706, p<0.05$ ) (Fig. $7 C, D$ ). On the other hand, a visible platform test conducted after the probe test revealed no significant differences among the groups for 5XFAD mice with bryostatin- $1\left(F_{(3,35)}=0.925 p>0.05\right)$ or with DCP-LA $\left(F_{(3,35)}=0.898, p>0.05\right)$ treatment (data not shown), indicating that neither PKC activator caused significant group differences in sensorimotor ability or escape motivation of the mice.

\section{Activation of PKC $\varepsilon$ alone by DCP-LA prevents rapid and substantial amyloid plaque formation in hippocampal CA1 stratum radiatum of $5 \mathrm{XFAD}$ mice}

A significant difference among groups for amyloid plaque formation was seen in 5XFAD mice $\left(F_{(2,119)}=5.317, p<0.01\right)$ (Fig. $7 E, F)$. Unlike Tg2576, which showed no amyloid deposition in hippocampi at 5 months old (Fig. 1iD, E), 5XFAD mice (without treatment) did show clear amyloid plaque deposition $(p<$ 0.001 ) (Fig. $7 E, F)$. The chronic DCP-LA treatment, however, significantly prevented amyloid deposition $(p<0.01)$ (Fig. $7 E, F)$. The results suggested that activation of $\mathrm{PKC} \varepsilon$ alone is sufficient to counteract aggressive amyloid plaque deposition in 5XFAD mice.
Activation of PKC $\varepsilon$ alone by DCP-LA prevents synaptic loss (per unit volume) in 5XFAD mice

Changes in the densities of postsynaptic dendritic spines were studied by immunohistochemistry and confocal microscopy (Fig. 8 A). By counting of fluorescent grains of the dendritic spine marker spinophilin, we found a significant difference among experimental groups for dendritic spines $\left(F_{(2,115)}=3.061, p<0.05\right)$ (Fig. $8 A, B)$. DCP-LA prevented this loss of dendritic spine density in 5XFAD mice $(p<0.05)$ (Fig. $8 A, B)$. This reduction was not the result of cell death at this age because there was no difference among groups in the number of pyramidal neurons in the CA1 area (cell viability test; $F_{(2,31)}=$ intensity $0.319, p=0.728$ ) (Fig. $8 E$ ) and no increase in apoptotic cell death (Fig. $8 F$ ).

Changes in the presynaptic compartment were examined with immunohistochemistry of the axonal bouton marker synaptophysin. At the level of confocal microscopy, one synaptophysin grain represented one axonal bouton (Fig. 8A). There was no significant difference among experimental groups for the number of synaptophysin grains and thus the number of axonal boutons (Fig. $8 A, C$ ). The number of presynaptic vesicles within axonal boutons was further analyzed with the immunofluorescence intensity of synaptophysin, a presynaptic vesicle membrane protein. The immunofluorescence intensity and thus the density of presynaptic vesicles within axonal boutons showed significant differences among experimental groups $\left(F_{(2,107)}=8.157, p<0.001\right)$ (Fig. $8 A, D)$. Whereas the number of axonal boutons showed a tendency that was not significant to decrease $(p=0.06)$ (Fig. $8 C$ ), presynaptic vesicle density significantly decreased in $5 \mathrm{XFAD}$ mice at 5 months old $(p<0.05)$ (Fig. 8D). Figure $8 D$ also shows that DCP-LA (5XFAD plus DCP-LA) protected (compared to 5XFAD plus vehicle; $p<0.001$ ) and even increased (compared to wild-type control treated with vehicle: wild type plus vehicle; $p<0.01$ ) the density of presynaptic vesicles. 
A CA1 stratum radiatum

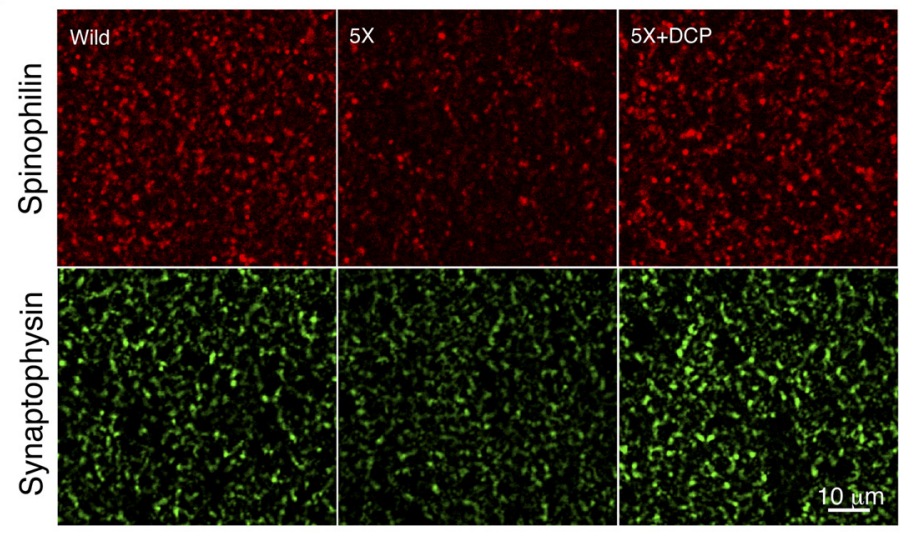

D Presynaptic vesicles

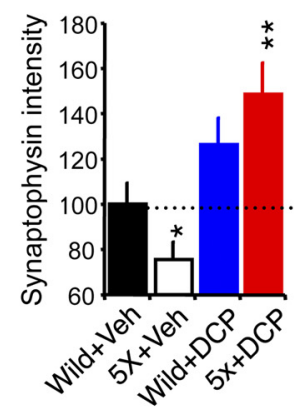

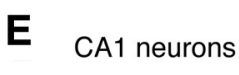

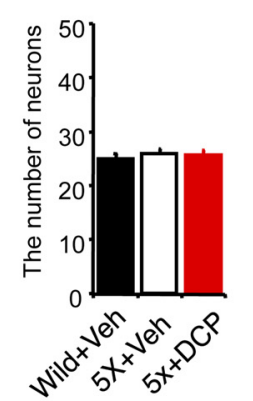

B

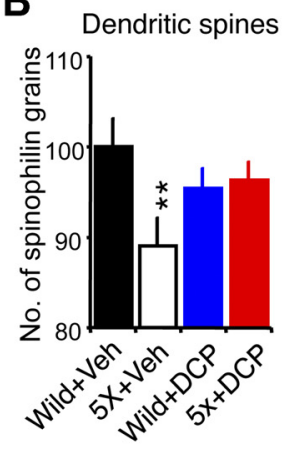

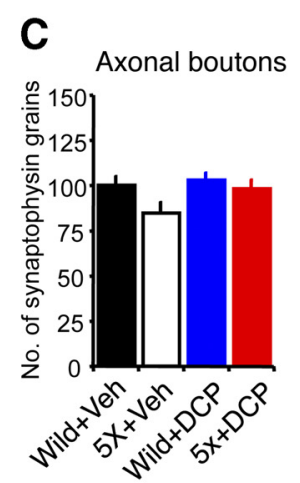

\section{CA1 synapses}
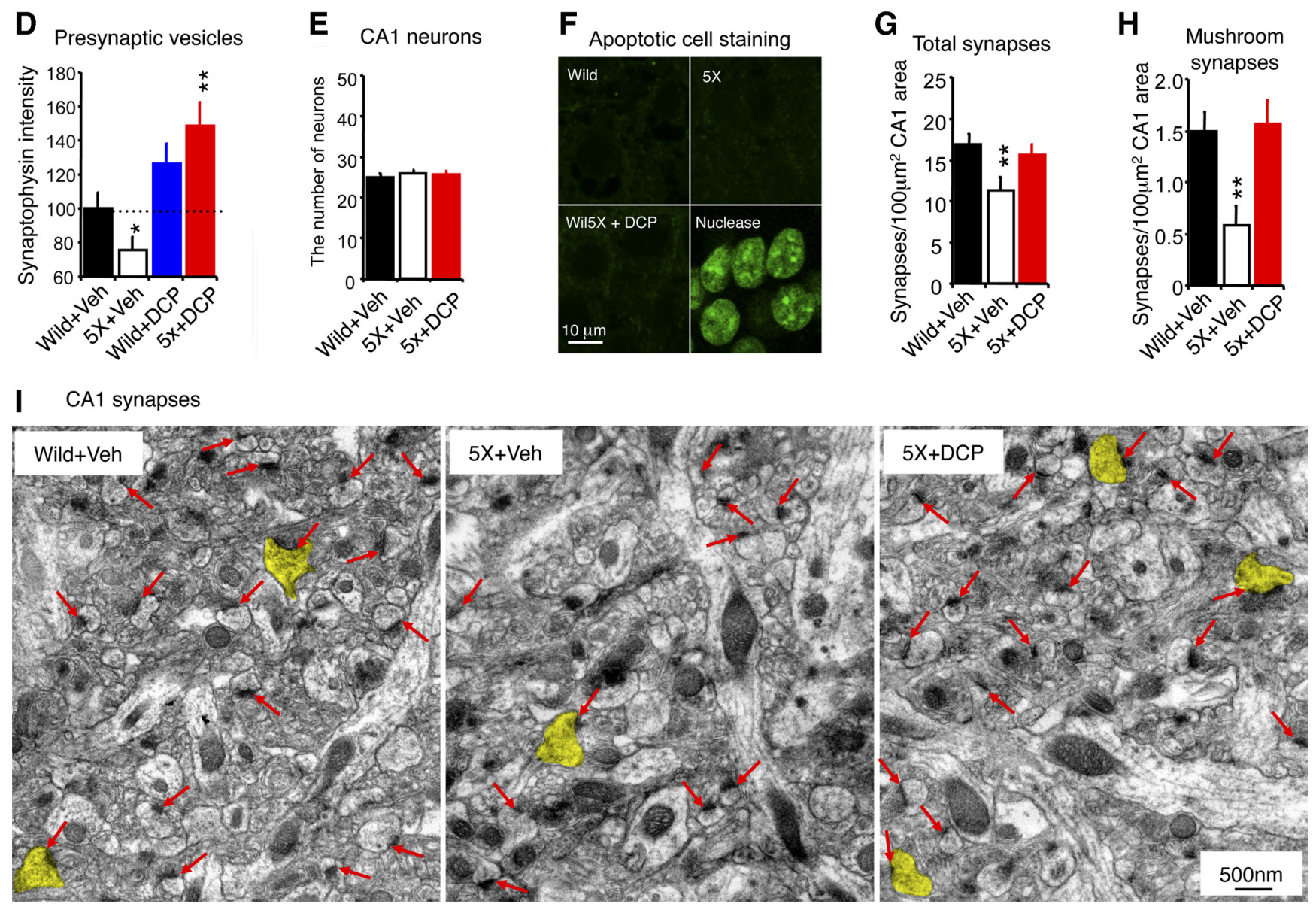

Figure 8. The PKC $\varepsilon$-specific activator DCP-LA prevents synaptic loss in hippocampal CA1 area of 5XFAD mice at 5 months old. $A$, Confocal microscopy and immunohistochemistry of the spinophilin and synaptophysin ( $n=3-4$ mice; $n=30-40$ sections of the CA1 area/group). $\boldsymbol{B}$, Reduction of the number of dendritic spines (spinophilin grains). $C$, No change of axonal bouton (synaptophysin grain) density in any experimental condition. $\boldsymbol{D}$, Reduction of the concentration of presynaptic vesicles in the axonal boutons determined by fluorescence intensity of the presynaptic vesicle membrane protein synaptophysin. $\boldsymbol{E}, \boldsymbol{F}, \mathrm{DCP}$-LA prevented the loss of dendritic spines and presynaptic vesicles. No changes in the density of pyramidal neuron nuclei $(\boldsymbol{E} ; n=3$ mice; $n=12$ sections of CA1 area/group) and apoptotic cell death by TUNEL staining ( $F ; n=3$ mice; $n=12$ hippocampal slices/group) were observed using nuclease-treated hippocampal cells for positive control staining. G-I, Electron microscopy of synaptic structures; yellow highlight, mushroom spine synapses; red arrow, synapses; 5X, 5XFAD transgenic mice; Bry, bryostatin-1; DCP, DCP-LA; Veh, vehicle; Data are shown as means \pm SEM; ${ }^{*} p \leq 0.05 ;{ }^{* *} p<0.01$.

Based on electron microscopy (Fig. 8 I), a significant difference among experimental groups was also observed for the total number of synapses $\left(F_{(2,100)}=6.059,4.483, p<0.01\right)$ (Fig. 8G,I) as well as for the number of mushroom spine synapses $\left(F_{(2,100)}=5.011, p<0.01\right)$ (Fig. $\left.8 H, I\right)$ in the proximal dendrites in hippocampal CA1 stratum radiatum of 5XFAD mice. The loss of all synapses in 5XFAD mice (69 $\pm 8 \%$, mean \pm SEM) in the presence of amyloid plaques was not significantly different, however, from the loss of all synapses in the Tg2576 mice $(65 \pm 8 \%)(p>0.59)$ in the absence of amyloid plaques. The loss of mushroom spine synapses in 5XFAD mice $(45 \pm 11 \%)$ was also not $(p>0.42)$ significantly different from the loss of mushroom spine synapses in Tg2576 mice $(51 \pm 12 \%)$. Nevertheless, these losses of synapses in both transgenic strains were all highly significant (Figs. $5 \mathrm{H}, \mathrm{I}$ and $8 G, H$ ). These results suggest, therefore, that the aggressive 
amyloid plaque deposition in the 5XFAD mice did not cause synaptic loss greater than that associated with elevation of soluble $\mathrm{A} \beta$ alone.

DCP-LA prevented the loss of the total number of spine synapses $(p<0.05)$ (Fig. $8 G, I)$ and the mushroom spine synapses, $p<0.01$ (Fig. $8 H, I$ ). These results suggest that activation of PKC $\varepsilon$ alone by DCP-LA can prevent synaptic loss in $5 \mathrm{XFAD}$ mice.

\section{Discussion}

Our results in the present study demonstrate that bryostatin-1, which activates $\mathrm{PKC} \varepsilon$ and to a lesser extent $\mathrm{PKC} \alpha$, prevented an increases in soluble $\mathrm{A} \beta$ protein that in turn suppresses $\mathrm{PKC} \varepsilon$ and PKC $\alpha$ expression and PKC-dependent BDNF production in the hippocampus, resulting in synaptic loss and memory deficits before amyloid plaque deposition in Tg2576 mice. Treatment with the PKC $\varepsilon$-specific activator DCP-LA in 5XFAD, moreover, had similar preventive effects against synaptic loss, amyloid plaque deposition, and memory deficits at 5 months, when extensive amyloid plaques, synaptic loss, and memory deficits do occur in the absence of treatment.

Previous studies used Western blot analysis to measure PKC $\varepsilon$ and PKC $\alpha$ in hippocampal neurons (Bar-Am et al., 2004). For these measurements, the entire hippocampal areas were assayed. The advantage of immunohistochemistry, however, as used in the present study is that we could observe both subtle changes in protein levels (defined by fluorescence intensity) and identify particular neuronal structures and/or compartments containing that protein or protein levels in distinct areas of the hippocampus. For example, immunohistochemistry (Fig. 4C-E) results demonstrated that the decrease in $\mathrm{PKC} \varepsilon$ protein level in the hippocampal CA1 area of Tg2576 mice was the result of the decreased numbers of presynaptic boutons that contained PKC $\varepsilon$ rather than a result of decreased PKC $\varepsilon$ levels in the individual boutons. A previous study, for another example, demonstrated that the number of total synapses was not changed in CA1 stratum radiatum (Dong et al., 2007), whereas our results demonstrate a significant decrease in the synapses per unit volume of CA1 stratum radiatum.

In the present study, we showed concomitantly occurring increased $\mathrm{A} \beta$ and decreased PKC $\varepsilon$ and $\alpha$ levels, all of which were reversed by $\mathrm{PKC}$ activators in the Tg2576 AD transgenic mice. Although we did not directly demonstrate that $\mathrm{A} \beta$ was causally related to the reduction of the two PKC isozymes $\alpha$ and $\varepsilon$, our results did suggest that $\mathrm{A} \beta$ lowers PKC $\varepsilon$ and $\alpha$ levels while enhanced PKC activation lowers $\mathrm{A} \beta$ levels.

Measurements in the present study with two AD transgenic species (TG2576 and 5XFAD) demonstrate a pathologic imbalance of a previously observed $\mathrm{PKC}-\mathrm{A} \beta$ interaction that helps explain a loss of synapses as measured by electromicroscopic visualization, immunohistochemical localization, and confocal structural visualization. This AD transgenic-specific synaptic loss is accompanied at first by elevation of soluble $\mathrm{A} \beta$ and then by increased numbers of amyloid plaques. It is also accompanied by reduction of the PKC $\alpha$ and $\varepsilon$ isozymes and by loss of learning and memory in the spatial water maze-training paradigm before increased amyloid plaques. All of these synaptic deficits, cognitive deficits, and $\mathrm{A} \beta$ abnormalities can be prevented by activators of the PKC $\alpha$ and $\varepsilon$ isozymes such as bryostatin-1. The synaptic loss, amyloid plaques, and cognitive deficits could be prevented by the activator of the PKC $\varepsilon$ isozyme, DCP-LA. These results have importance not only for the mechanistic basis of early synaptic loss in $\mathrm{AD}$, but also for the development of potent and specific therapeutics for both the symptoms and progression of AD.

An increase in soluble $\mathrm{A} \beta$ was previously first seen in TG2576 mice at 2 to 3 months of age (Hsiao et al., 1996; Westerman et al., 2002). A decrease in dendritic spine density was detected in the hippocampus as early as $4-4.5$ months, whereas a decline in synaptic transmission occurred by 5 months (Lanz et al., 2003; Jacobsen et al., 2006). According to previous studies, an early defect of learning and memory was evident at 5 months for contextual fear conditioning (Jacobsen et al., 2006) and at about 6 months for water maze training (Westerman et al., 2002). The scattered formation of amyloid plaque formation was found to start at 9-12 months (Westerman et al., 2002; Jacobsen et al., 2006). By using a more difficult training regimen in the present study, we were able to show that cognitive deficits occurred in the 5 month Tg2576, months before significant amyloid plaques could be detected in the brains.

Our results demonstrate that PKC isozymes are critically involved in the $\mathrm{AD}$ pathology. $\mathrm{A} \beta$ has previously been shown to cause in vitro reductions of $\mathrm{PKC}$ isozymes and to downregulate $\mathrm{PKC}$ by the binding of PKC to a putative PKC substrate domain (A $\beta 28$-30) (Favit et al., 1998; Lee et al., 2004). Furthermore, PKC reduction has been previously observed in the brains and peripheral tissues of $\mathrm{AD}$ versus aged-matched, nondemented control patients (Masliah et al., 1990; Matsushima et al., 1996; Favit et al., 1998). Conversely, PKC has previously been suggested to reduce A $\beta$ by activating $\alpha$-secretase (Skovronsky et al., 2000; Bell et al., 2008 ), increasing the degradation of $\mathrm{A} \beta$ via the endothelinconverting enzyme (ECE) (Choi et al., 2006; Nelson and Alkon, 2009) and, most recently, by inhibiting the $A \beta$-forming $\beta$-secretase (Wang et al., 2008).

The PKC activators produced only a moderate and transient activation of $\alpha$-secretase in neuronal cells (Nelson et al., 2009). However, these activators did substantially increase ECE activity to $180 \%$ of control levels (Nelson et al., 2009). These data suggest that $\mathrm{PKC} \varepsilon$ activators reduce $\mathrm{A} \beta$ levels by largely increasing the rate of $A \beta$ degradation by ECE and not by activating nonamyloidogenic amyloid precursor protein metabolism, consistent with earlier results showing overexpression of $\mathrm{PKC} \varepsilon$ in $\mathrm{AD}$ transgenic mice (Choi et al., 2006). However, a recent report did show that PKC activators could also inhibit the amyloidogenic pathway via inhibition of $\beta$-site of APP cleaving enzyme (Fu et al., 2009). Bryostatin significantly prevented the increased levels of $\mathrm{A} \beta$ oligomers within extranuclear cytoplasmic compartments of CA1 neurons in Tg2576 mice (Figs. 2, 3). DCP-LA also protected against the increase in amyloid plaque formation in the $5 \mathrm{XFAD}$ mice (Fig. 7F). Thus, the present study confirmed that bryostatin- 1 and DCP-LA reduce $\mathrm{A} \beta$ levels in vivo.

Functional deficits of PKC isozymes could have at least two important consequences on synapses: synaptic loss/impairment as the result of an increased $A \beta$ formation, and an impaired synaptogenesis due to PKC dysfunction. A $\beta$ oligomers decrease synaptic transmission, reduce NMDA receptors in the postsynaptic membrane, reduce activity-dependent increases in intracellular $\mathrm{Ca}^{2+}$, and increase protein phosphatase activity, resulting in synaptic loss (Snyder et al., 2005; Shankar et al., 2007). Our results suggest that these parameters of synaptic dysfunction are arising from the loss of presynaptic boutons and/or reduction of PKC $\varepsilon$ in presynaptic boutons as a consequence of increased soluble $\mathrm{A} \beta$ - before amyloid plaque deposition.

A number of in vitro studies have implicated PKC, particularly PKC $\varepsilon$, in the induction of synaptogenesis. The first pathway involves local contact between dendrites and astrocytes mediated 
by cell-cell contact through integrin receptors activating phospholipase A2, which produces arachidonic acid, a PKC activator. After adding astrocytes to cultured neurons, Hama et al. (2004) found increased punctate signals distal to sites of astrocytic contact that stained positively for PSD-95 and synaptotagmin I, which are markers for postsynaptic and presynaptic cell structures, respectively, indicating new synapse growth. This growth was associated with increased phosphorylation of MARCKS, a PKC substrate. Blocking integrins with the disintegrin peptide echistatin or the peptide RGDS abolished the increase, and PLA2 inhibitors greatly reduced it, indicating the involvement of integrins and arachidonic acid. PKC inhibitors blocked the synaptogenic effect and phorbol esters increased it, suggesting that $\mathrm{PKC}$ is involved. PKC may also induce synaptogenesis directly by activating structural changes through its phosphorylation substrates, GAP-43, MARCKS, and adducin. A third PKC-regulated pathway involves neurotrophin factors that are important for synaptogenesis and stability. PKC activates the mRNA-stabilizing proteins $\mathrm{HuD}$ and subsequently promotes protein synthesis and synaptogenesis (Hongpaisan and Alkon, 2007). HuD activity enhances the production of GDNF, BDNF, and NGF (Carlin et al., 1980) (Cho and D. L. Alkon, unpublished observations).

Our data suggest that increased levels of $\mathrm{A} \beta$ inhibit $\mathrm{PKC}$, which causes reduction in $\mathrm{HuD}$ activity and thereby lowers the levels of neurotrophic factors, such as BDNF (Fig. 6A-D), leading to reduced synaptogenesis. We found no increase in astrocyte activity before amyloid plaque formation. However, it is evident that an increase in the number of astrocytes (gliosis) may cause synaptic loss after amyloid plaque formation (Mandybur, 1989; Brun et al., 1995). Another possibility is that decreased PKC $\varepsilon$ directly causes structural changes through phosphorylation of PKC substrates such as, GAP-43, MARCKS, and adducin.

Although amyloid plaque deposition was previously observed in 5XFAD mice at 2 months old (Oakley et al., 2006), loss of synaptophysin concentration (consistent with synaptic loss) did not occur until 4 months of age (Oakley et al., 2006). For Y-maze training, a memory deficit was previously observed in 5XFAD mice at 4 to 5 (but not at 2) months of age (Oakley et al., 2006). Spatial memory deficits were previously measured in 5XFAD mice at 4-6 months old after water maze training (Ohno et al., 2006). In Tg2576 mice, loss of dendritic spine density was previously observed at 4.5 months (Lanz et al., 2003). Our electron microscopic data showed in the present study that there were significantly comparable synaptic losses in both the 5XFAD versus Tg2576 mice at the age of 5 months. All of these data taken together suggest that amyloid plaque accumulation initially does not add to the synaptic loss or the cognitive dysfunction caused by soluble $\mathrm{A} \beta$ oligomers.

As demonstrated by the above results, bryostatin-1, an activator of PKC $\varepsilon$ and PKC $\alpha$, can almost entirely prevent the loss of synapses, the loss of PKC $\alpha$ and $\varepsilon$, elevation of soluble $\mathrm{A} \beta$, and impairment of spatial learning and memory in the Tg2576 transgenic $\mathrm{AD}$ strain months before the deposition of amyloid plaques. Similarly, DCP-LA, a PKC $\varepsilon$-specific activator, entirely prevents synaptic loss, amyloid plaques, and memory impairment in the much more aggressive 5XFAD mouse strain. Because PKC activation also has been shown to effectively inhibit GSK-3 $\beta$ (Goode et al., 1992), which is largely responsible for hyperphosphorylation of tau (Ishiguro et al., 1993), these same PKC activators may also prevent the deposition of another major pathophysiologic hallmark of $\mathrm{AD}$, neurofibrillary tangles (Ballatore et al., 2007).

The in vivo results presented here confirm for the first time the reciprocal effects of $\mathrm{A} \beta$ and $\mathrm{PKC}$ isozymes on the loss of synapses in the brains of $\mathrm{AD}$ transgenic mice. The dramatic efficacy of nontumorigenic PKC $\alpha$ and $\varepsilon$ activators (bryostatin-1, DCP-LA) on all of the major pathologic and synaptic AD hallmarks in both $\mathrm{AD}$ transgenic strains greatly encourages the view that these $\mathrm{PKC}$ activators could have significant efficacy for treating both the symptoms and the progressive neurodegeneration in $\mathrm{AD}$ patients as will soon be initially tested in the first Food and Drug Administration-approved Phase II trial of bryostatin-1 for AD.

\section{References}

Ballatore C, Lee VM, Trojanowski JQ (2007) Tau-mediated neurodegeneration in Alzheimer's disease and related disorders. Nat Rev Neurosci 8:663-672.

Bar-Am O, Yogev-Falach M, Amit T, Sagi Y, Youdim MB (2004) Regulation of protein kinase $\mathrm{C}$ by the anti-Parkinson drug, MAO-B inhibitor, rasagiline and its derivatives, in vivo. J Neurochem 89:1119-1125.

Bell KF, Zheng L, Fahrenholz F, Cuello AC (2008) ADAM-10 over-expression increases cortical synaptogenesis. Neurobiol Aging 29:554-565.

Brun A, Liu X, Erikson C (1995) Synapse loss and gliosis in the molecular layer of the cerebral cortex in Alzheimer's disease and in frontal lobe degeneration. Neurodegeneration 4:171-177.

Bussière T, Bard F, Barbour R, Grajeda H, Guido T, Khan K, Schenk D, Games D, Seubert P, Buttini M (2004) Morphological characterization of Thioflavin-S-positive amyloid plaques in transgenic Alzheimer mice and effect of passive Abeta immunotherapy on their clearance. Am J Pathol 165:987-995.

Carlin RK, Grab DJ, Cohen RS, Siekevitz P (1980) Isolation and characterization of postsynaptic densities from various brain regions: enrichment of different types of postsynaptic densities. J Cell Biol 86:831-845.

Cheng IH, Scearce-Levie K, Legleiter J, Palop JJ, Gerstein H, Bien-Ly N, Puoliväli J, Lesné S, Ashe KH, Muchowski PJ, Mucke L (2007) Accelerating amyloid-beta fibrillization reduces oligomer levels and functional deficits in Alzheimer disease mouse models. J Biol Chem 282:23818-23828.

Choi DS, Wang D, Yu GQ, Zhu G, Kharazia VN, Paredes JP, Chang WS, Deitchman JK, Mucke L, Messing RO (2006) PKCepsilon increases endothelin converting enzyme activity and reduces amyloid plaque pathology in transgenic mice. Proc Natl Acad Sci U S A 103:8215-8220.

Devi L, Anandatheertharavada HK (2010) Mitochondrial trafficking of APP and alpha synuclein: relevance to mitochondrial dysfunction in Alzheimer's disease and Parkinson's disease. Biochim Biophys Acta 1802:11-19.

Dong H, Martin MV, Chambers S, Csernansky JG (2007) Spatial relationship between synapse loss and beta-amyloid deposition in $\operatorname{Tg} 2576$ mice. J Comp Neurol 500:311-321.

Favit A, Grimaldi M, Nelson TJ, Alkon DL (1998) Alzheimer's-specific effects of soluble beta-amyloid on protein kinase C-alpha and -gamma degradation in human fibroblasts. Proc Natl Acad Sci USA 95:5562-5567.

Fu H, Dou J, Li W, Cui W, Mak S, Hu Q, Luo J, Lam CS, Pang Y, Youdim MB, Han Y (2009) Promising multifunctional anti-Alzheimer's dimmer bis(7)-Cognitin acting as an activator of protein kinase $C$ regulates activities of alpha-secretase and BACE-1 concurrently. Eur J Pharmacol 623:14-21.

Geinisman Y, Berry RW, Disterhoft JF, Power JM, Van der Zee EA (2001) Associative learning elicits the formation of multiple-synapse boutons. J Neurosci 21:5568-5573.

Goode N, Hughes K, Woodgett JR, Parker PJ (1992) Differential regulation of glycogen synthase kinase- 3 beta by protein kinase $\mathrm{C}$ isotypes. J Biol Chem 267:16878-16882.

Hama H, Hara C, Yamaguchi K, Miyawaki A (2004) PKC signaling mediates global enhancement of excitatory synaptogenesis in neurons triggered by local contact with astrocytes. Neuron 41:405-415.

Hongpaisan J, Alkon DL (2007) A structural basis for enhancement of longterm associative memory in single dendritic spines regulated by PKC. Proc Natl Acad Sci U S A 104:19571-19576.

Hongpaisan J, Winters CA, Andrews SB (2004) Strong calcium entry activates mitochondrial superoxide generation, up regulating kinase signaling in hippocampal neurons. J Neurosci 24:10878-10887.

Hsiao K, Chapman P, Nilsen S, Eckman C, Harigaya Y, Younkin S, Yang F, Cole G (1996) Correlative memory deficits, Abeta elevation, and amyloid plaques in transgenic mice. Science 274:99-102. 
Ishiguro K, Shiratsuchi A, Sato S, Omori A, Arioka M, Kobayashi S, Uchida T, Imahori K (1993) Glycogen synthase kinase 3 beta is identical to tau protein kinase I generating several epitopes of paired helical filaments. FEBS Lett 325:167-172.

Jacobsen JS, Wu CC, Redwine JM, Comery TA, Arias R, Bowlby M, Martone R, Morrison JH, Pangalos MN, Reinhart PH, Bloom FE (2006) Earlyonset behavioral and synaptic deficits in a mouse model of Alzheimer's disease. Proc Natl Acad Sci U S A 103:5161-5166.

Kanno T, Yamamoto H, Yaguchi T, Hi R, Mukasa T, Fujikawa H, Nagata T, Yamamoto S, Tanaka A, Nishizaki T (2006) The linoleic acid derivative DCP-LA selectively activates PKC-epsilon, possibly binding to the phosphatidylserine binding site. J Lipid Res 47:1146-1156.

Kawarabayashi T, Younkin LH, Saido TC, Shoji M, Hsiao Ashe KH, Younkin SG (2001) Age-dependent changes in brain, CSF, and plasma amyloid beta protein in the Tg2576 transgenic mouse model of Alzheimer's disease. J Neurosci 21:372-381.

Kayed R, Head E, Thompson JL, McIntire TM, Milton SC, Cotman CW, Glabe CG (2003) Common Structure of soluble amyloid oligomers implies common mechanism of pathogenesis. Science 300:486-489.

Kirov SA, Petrak LJ, Fiala JC, Harris KM (2004) Dendritic spines disappear with chilling but proliferate excessively upon rewarming of mature hippocampus. Neuroscience 127:69-80.

Lanz TA, Carter DB, Merchant KM (2003) Dendritic spine loss in the hippocampus of young PDAPP and Tg2576 mice and its prevention by the ApoE2 genotype. Neurobiol Dis 13:246-253.

Lee W, Boo JH, Jung MW, Park SD, Kim YH, Kim SU, Mook-Jung I (2004) Amyloid beta peptide directly inhibits PKC activation. Mol Cell Neurosci 26:222-231.

Mandybur TI (1989) Cerebral amyloidangiopathy and astrocytic gliosis in Alzheimer's disease. Acta Neuropathol 78:329-331.

Masliah E, Cole G, Shimohama S, Hansen L, DeTeresa R, Terry RD, Saitoh T (1990) Differential involvement of protein kinase C isozymes in Alzheimer's disease. J Neurosci 10:2113-2124.

Masliah E, Hansen L, Albright T, Mallory M, Terry RD (1991) Immunoelectron microscopic study of synaptic pathology in Alzheimer's disease. Acta Neuropathol 81:428-433.

Matsushima H, Shimohama S, Chachin M, Taniguchi T, Kimura J (1996) $\mathrm{Ca}^{2+}$-dependent and $\mathrm{Ca}^{2+}$-independent protein kinase $\mathrm{C}$ changes in the brain of patients with Alzheimer's disease. J Neurochem 67:317-323.

Nelson TJ, Alkon DL (2009) Neuroprotective versus tumorigenic protein kinase C activators. Trends Biochem Sci 34:136-145.

Nelson TJ, Cui C, Luo Y, Alkon DL (2009) Reduction of beta-amyloid levels by novel protein kinase C(epsilon) activators. J Biol Chem 284:34514-34521.

Nitta A, Fukumitsu H, Kataoka H, Nomoto H, Furukawa S (1997) Administration of corticosterone alters intracellular localization of brainderived neurotrophic factor-like immunoreactivity in the rat brain. Neurosci Lett 226:115-118.

Oakley H, Cole SL, Logan S, Maus E, Shao P, Craft J, Guillozet-Bongaarts A, Ohno M, Disterhoft J, Van Eldik L, Berry R, Vassar R (2006) Intraneuronal beta-amyloid aggregates, neurodegeneration, and neuron loss in transgenic mice with five familial Alzheimer's disease mutations: potential factors in amyloid plaque formation. J Neurosci 26:10129-10140.

Ohno M, Chang L, Tseng W, Oakley H, Citron M, Klein WL, Vassar R, Disterhoft JF (2006) Temporal memory deficits in Alzheimer's mouse models: rescue by genetic deletion of BACE1. Eur J Neurosci 23:251-260.
Pascale A, Amadio M, Scapagnini G, Lanni C, Racchi M, Provenzani A, Govoni S, Alkon DL, Quattrone A (2005) Neuronal ELAV proteins enhance mRNA stability by a PKCalpha-dependent pathway. Proc Natl Acad Sci U S A 102:12065-12070.

Saitoh T, Sundsmo M, Roch JM, Kimura N, Cole G, Schubert D, Oltersdorf T, Schenk DB (1989) Secreted form of amyloid beta protein precursor is involved in the growth regulation of fibroblasts. Cell 58:615-622.

Shankar GM, Bloodgood BL, Townsend M, Walsh DM, Selkoe DJ, Sabatini BL (2007) Natural oligomers of the Alzheimer's amyloid- $\beta$ protein induce reversible synapse loss by modulating an NMDA-type glutamate receptor-dependent signaling pathway. J Neurosci 27:2866-2875.

Shirai Y, Adachi N, Saito N (2008) Protein kinase Cepsilon: function in neurons FEBS J 275:3988-3994.

Sieber FE, Traystman RJ, Brown PR, Martin LJ (1998) Protein kinase C expression and activity after global incomplete cerebral ischemia in dogs. Stroke 29:1445-1453.

Skovronsky DM, Moore DB, Milla ME, Doms RW, Lee VM (2000) Protein kinase C-dependent alpha-secretase competes with beta-secretase for cleavage of amyloid-beta precursor protein in the trans-Golgi network. J Biol Chem 275:2568-2575.

Snyder EM, Nong Y, Almeida CG, Paul S, Moran T, Choi EY, Nairn AC, Salter MW, Lombroso PJ, Gouras GK, Greengard P (2005) Regulation of NMDA receptor trafficking by amyloid- $\beta$. Nat Neurosci 8:1051-1058.

Suh YH, Checler F (2002) Amyloid precursor protein, presenilins, and alpha-synuclein: molecular pathologenesis and pharmacological applications in Alzheimer's disease. Pharmacol Rev 54:469-525.

Sun MK, Hongpaisan J, Nelson TJ, Alkon DL (2008) Poststroke neuronal rescue and synaptogenesis mediated in vivo by protein kinase $\mathrm{C}$ in adult brains. Proc Natl Acad Sci U S A 105:13620-13625.

Sun MK, Hongpaisan J, Alkon DL (2009) Postischemic PKC activation rescues retrograde and anterograde long-term memory. Proc Natl Acad Sci U S A 106:14676-14680.

Sze CI, Troncoso JC, Kawas C, Mouton P, Price DL, Martin LJ (1997) Loss of the presynaptic vesicle protein synaptophysin in hippocampus correlates with cognitive decline in Alzheimer disease. J Neuropathol Exp Neurol 56:933-944.

Terry RD, Masliah E, Salmon DP, Butters N, DeTeresa R, Hill R, Hansen LA, Katzman R (1991) Physical basis of cognitive alterations in Alzheimer's disease: synaptic loss is the major correlate of cognitive impairment. Ann Neurol 30:572-580.

Wang L, Shim H, Xie C, Cai H (2008) Activation of protein kinase C modulates BACE1-mediated beta-secretase activity. Neurobiol Aging 29:357-367.

Westerman MA, Cooper-Blacketer D, Mariash A, Kotilinek L, Kawarabayashi T, Younkin LH, Carlson GA, Younkin SG, Ashe KH (2002) The relationship between Abeta and memory in the Tg2576 mouse model of Alzheimer's disease. J Neurosci 22:1858-1867.

Wetmore C, Cao YH, Pettersson RF, Olson L (1991) Brain-derived neurotrophic factor: subcellular compartmentalization and interneuronal transfer as visualized with anti-peptide antibodies. Proc Natl Acad Sci U S A 88:9843-9847.

Wetmore CJ, Cao Y, Pettersson RF, Olson L (1993) Brian-derived neurotrophic factor (BDNF) peptide antibodies: characterization using a vaccinia virus expression system. J Histochem Cytochem 41:521-533. 